NBER WORKING PAPER SERIES GOVERNMENT INVESTMENT AND FISCAL STIMULUS IN THE SHORT AND
LONG RUNS

Eric M. Leeper

Todd B. Walker

Shu-Chun Susan Yang

Working Paper 15153

http://www.nber.org/papers/w15153

NATIONAL BUREAU OF ECONOMIC RESEARCH

1050 Massachusetts Avenue

Cambridge, MA 02138

July 2009

We thank Juan Contreras, Paul Cullinan, Bob Dennis, Jonathan Huntley, and Bob Sunshine for helpful comments. The views expressed in this paper are those of authors and should not be interpreted as those of the Congressional Budget Office, or the National Bureau of Economic Research.

NBER working papers are circulated for discussion and comment purposes. They have not been peerreviewed or been subject to the review by the NBER Board of Directors that accompanies official NBER publications.

(C) 2009 by Eric M. Leeper, Todd B. Walker, and Shu-Chun Susan Yang. All rights reserved. Short sections of text, not to exceed two paragraphs, may be quoted without explicit permission provided that full credit, including (C) notice, is given to the source. 
Government Investment and Fiscal Stimulus in the Short and Long Runs

Eric M. Leeper, Todd B. Walker, and Shu-Chun Susan Yang

NBER Working Paper No. 15153

July 2009

JEL No. E6,E62,H54

\begin{abstract}
$\underline{\text { ABSTRACT }}$
This paper contributes to the debate about fiscal multipliers by studying the impacts of government investment in conventional neoclassical growth models. The analysis focuses on two dimensions of fiscal policy that are critical for understanding the effects of government investment: implementation delays associated with building public capital projects and expected future fiscal adjustments to debt-financed spending. Implementation delays can produce small or even negative labor and output responses in the short run; anticipated fiscal financing adjustments matter both quantitatively and qualitatively for long-run growth effects. Taken together, these two dimensions have important implications for the short-run and long-run impacts of fiscal stimulus in the form of higher government infrastructure investment. The analysis is conducted in several models with features relevant for studying government spending, including utility-yielding government consumption, time-to-build for private investment, and government production.
\end{abstract}

Eric M. Leeper

Department of Economics

304 Wylie Hall

Indiana University

Bloomington, IN 47405

and NBER

eleeper@indiana.edu

Todd B. Walker

Department of Economics

105 Wylie Hall

Indiana University

Bloomington, IN 47405

walkertb@indiana.edu
Shu-Chun Susan Yang

Congressional Budget Office

U.S. Congress

2nd and D Streets, SW

Washington, DC 20515

susan.yang@cbo.gov 


\title{
GOVERNMENT INVESTMENT AND FISCAL STIMULUS IN THE SHORT AND LONG RUNS
}

\author{
ERIC M. LEEPER, TODD B. WALKER, AND SHU-CHUN S. YANG
}

\section{IntRoduCTION}

The recession that began in December 2007 will be the longest and the deepest economic downturn since the Great Depression. The Congressional Budget Office has projected that the economic contraction will last through most of 2009, with only a slow recovery beginning in 2010 [Congressional Budget Office (2009b)]. To prevent further deterioration and facilitate the recovery, the U.S. Congress passed the $\$ 787$ billion American Recovery and Reinvestment Act, in addition to the $\$ 125$ billion provided by the Economic Stimulus Act of 2008. This unprecedentedly large scale of discretionary countercyclical fiscal actions has certainly stimulated interest in and debate about the effects of fiscal policy. ${ }^{1}$

In addition to its large scale, this fiscal stimulus differs from those in the recent past by relying more on spending increases and less on tax cuts. Nearly two-thirds of the stimulus package is direct government spending and transfers. That spending includes $\$ 44$ billion for infrastructure expenditures on water quality, transportation, and housing, and another $\$ 88$ billion in direct federal spending on energy, innovative technology, and federal buildings. [Congressional Budget Office (2009a)]. These infrastructure provisions, which are unusual for countercyclical fiscal packages in the past 30 years, have revived the role of government investment as a countercyclical tool.

This paper contributes to the policy debate by conducting a positive analysis of government investment in dynamic stochastic general equilibrium (DSGE) models. We focus on two dimensions that are critical to evaluate the effects of government investment: the timing of spending outlays and the methods of future fiscal financing. With respect to the former,

Date: July 3, 2009. Department of Economics, Indiana University and NBER, eleeper@indiana.edu; Department of Economics, Indiana University, walkertb@indiana.edu; Congressional Budget Office, susan.yang@cbo.gov. We thank Juan Contreras, Paul Cullinan, Bob Dennis, Jonathan Huntley, and Bob Sunshine for helpful comments. The views expressed in this paper are those of authors and should not be interpreted as those of the Congressional Budget Office.

${ }^{1}$ The American Recovery and Reinvestment Act in unusually large. Alone it provides an estimated $\$ 719$ billion stimulus for fiscal years 2009 to 2011 [Congressional Budget Office (2009a)], roughly equivalent to 5 percent of GDP in 2008. The Economic Growth and Tax Relief Reconciliation Act of 2001, partially motivated by the 2001 recession, provided $\$ 202$ billion stimulus for fiscal years 2001 to 2003 [Joint Committee on Taxation (2001)], roughly equivalent to 2 percent of GDP in 2001. The Economic Recovery Tax Act of 1981 provided tax relief of about $\$ 130$ billion for fiscal years 1981 to 1983 [estimated by the Joint Committee on Taxation as documented in Congressional Quarterly Press (2006)], roughly equivalent to 4 percent of GDP in 1981. (At the same time, the Omnibus Budget Reconciliation Act of 1981 cut government spending by $\$ 35.2$ billion [Congressional Quarterly Press (2006)].) Another large countercyclical fiscal action in the post-war era was the Tax Reduction Act of 1975 , which provided a tax reduction of $\$ 21$ billion and additional spending of $\$ 2$ billion [Congressional Quarterly Press (2006)]; the total was 1.4 percent of GDP in 1975 . 
government investment is typically subject to several delays. In addition to the delay in recognizing a need to act, government investment, especially infrastructure projects, is subject to substantial implementation delays. Projects often require coordination among federal, state, and local governments and they are subjected to a long process of planning, bidding, contracting, construction, and evaluation. These delays can make the economic benefits from government investment difficult to synchronize with the business cycle.

With respect to fiscal financing, how deficit spending will be financed has important implications for the effects of government investment at longer horizons. This issue is particularly important for the current fiscal situation. A quickly deteriorating federal government budget situation, coupled with projections of exploding government debt due to rising health care costs and American demographic shifts [Congressional Budget Office (2007)], suggest that future policies must be expected to adjust to maintain budget solvency. ${ }^{2}$ Distortions from higher expected income tax rates or lower expected government spending can undermine the policy objective of promoting growth through productive government investment.

We examine these two issues in DSGE models calibrated to U.S. data. The delays between authorization of a government spending plan and completion of an investment project are modeled by a time-to-build technology for public capital projects, as in Kydland and Prescott (1982), and investigate the implications of various periods of time-to-build. The estimates of outlay streams associated with an enacted spending bill provide a schedule by which the spending would likely occur. Delays in implementing government investment imply that consumers and firms learn about spending plans before they are carried out. When private agents act on the expectation of higher infrastructure spending, the economy can be affected even before the public capital projects are completed. ${ }^{3}$

So long as public capital is productive, the expectation of higher infrastructure spending generates a positive wealth effect, which discourages work and encourages consumption. Because private investment projects typically do not entail the substantial delays associated with public projects, it takes less time to build private capital. Private investment and employment, therefore, may be delayed until the public capital is on line and raises the productivity of private inputs. Compared with the situation without implementation delays, in the short run private investment is lower and labor impacts may be small or even negative. Output can fall in the short run in response to an increase in government investment. This result is analogous to the phased-in tax cuts enacted in 2001 and 2003, where expectations of future tax cuts may have induced workers and firms to delay work and production, retarding the recovery from the 2001 recession [House and Shapiro (2006)].

To examine the second issue - the consequences of alternative methods of financing the government spending — we consider adjustments in various fiscal instruments to stabilize the government debt-to-output ratio, including reductions in transfers or government consumption, or increases in capital or labor income taxes. Accounting for future fiscal adjustments is essential to evaluate the impact of government investment over longer horizons. Under

\footnotetext{
${ }^{2}$ The ratio of federal debt held by the public to GDP rose from 0.33 in 2001 to 0.38 in 2008 [table B78 of Economic Report of the President (2009)]. In baseline projections by the Congressional Budget Office (2009b), this ratio increases to 0.56 in 2019.

${ }^{3}$ This phenomenon is the public investment analog to tax foresight studied by Yang (2005) and Leeper, Walker, and Yang $(2008,2009)$ and war spending foresight examined by Ramey (2008).
} 
lump-sum financing, if public capital raises productivity of private production inputs, productive government investment promotes economic growth. This result, however, overlooks the possible contractionary effects introduced by distorting fiscal adjustments to stabilize government debt. We find that if public capital is not sufficiently productive, then government investment can be contractionary in the long run as the disincentive to invest and work due to expected fiscal adjustments can dominate the higher productivity of private inputs from expansion of public capital. ${ }^{4}$ In addition, we find that the speed of fiscal adjustment is a significant factor in determining the ability of government spending to offset cyclical movements in macro aggregates. The impact of a deficit-financed increase in government spending will be severely mitigated if the deficit is retired quickly through distortionary fiscal instruments.

Our aim is to employ widely used models to analyze these two factors in order to better connect our findings to existing literature. Although widely used, the models cannot adequately capture many of the aspects of the U.S. economy that are important for making predictions about the consequences of the American Recovery and Reinvestment Act or other policy actions designed to lift the economy out of the 2007-2009 recession. Because the Act includes substantial authorizations for infrastructure spending, this analysis can nevertheless highlight factors associated with expansions in government investment that are important for understanding the impacts of government investment in the short run and the long run.

\section{The MOdeL}

We analyze the effects of government investment and fiscal financing using several variants of the neoclassical growth model described in this section. The model incorporates real rigidities often seen in the class of DSGE policy models estimated with data, including habit formation in consumption, investment adjustment costs, and variable utilization rates for private capital [Smets and Wouters (2003, 2007), Bouakez and Rebei (2007), and Leeper, Plante, and Traum (2009)]. Across the models used here, government investment takes the form of productive public capital and is subject to a substantial time-to-build lag. Also, increases in government investment are debt-financed and, therefore, engender future fiscal adjustments that stabilize the debt-output ratio.

2.1. The Private Sector. The model economy consists of a representative agent, a representative firm, and a government. The agent derives utility from consumption $\left(C_{t}\right)$ and leisure $\left(1-L_{t}\right)$. The utility function takes the form

$$
U_{t} \equiv \frac{1}{1-e}\left(\frac{C_{t}}{C_{t-1}^{b}}\right)^{1-e}+\chi \frac{\left(1-L_{t}\right)^{1-\theta}-1}{1-\theta},
$$

\footnotetext{
${ }^{4}$ Barro (1990), Lau (1995), and Glomm and Ravikumar (1999) examine government spending impacts when distorting taxes are used to finance it, whereas Finn (1993), Ambler and Paquet (1996) assume lumpsum taxes do the financing. Kamps (2004) considers both distorting and non-distorting financing.
} 
where $e$ and $\theta$ are the inverses of elasticities of intertemporal substitution of consumption and leisure $(e>0$ and $\theta \geq 0)$, and $\chi$ is the utility weight on leisure. Utility depends on current and last-period consumption; $b$ indicates the degree of internal habit formation. ${ }^{5}$

The infinitely lived agent maximizes expected lifetime utility

$$
E_{t} \sum_{t=0}^{\infty} \beta^{t} U_{t}\left(C_{t}, C_{t-1}, L_{t}\right),
$$

subject to the budget constraint

$$
C_{t}+I_{t}+B_{t}+\psi\left(u_{t}\right) K_{t-1}=\left(1-\tau_{t}^{K}\right) r_{t} u_{t} K_{t-1}+\left(1-\tau_{t}^{L}\right) w_{t} L_{t}+R_{t-1} B_{t-1}+T_{t},
$$

and the law of motion for private capital

$$
K_{t}=(1-\delta) K_{t-1}+\Omega\left(I_{t}, I_{t-1}\right) .
$$

$B_{t}$ is government debt issued at $t$, which pays $R_{t} B_{t}$ units of goods at $t+1$. We introduce a capital utilization rate, $u_{t}$, as in Smets and Wouters (2003) and Christiano, Eichenbaum, and Evans (2005). The steady state capital utilization rate is assumed to be $u=1$ and $\psi(1)=0$. Increases from the steady state utilization rate incurs a cost, $\psi\left(u_{t}\right) K_{t-1}$, where $\psi\left(u_{t}\right)$ is an increasing, convex function. ${ }^{6} u_{t} K_{t-1}$ represents the effective units of private capital. The rental rate for one effective unit of private capital is $r_{t}$ and the wage rate is $w_{t}$. $\tau_{t}^{K}$ and $\tau_{t}^{L}$ are proportional tax rates levied on capital and labor income. $T_{t}$ is lump-sum transfers. Following Burnside, Eichenbaum, and Fisher (2004), we assume investment is subject to an adjustment cost. Net investment is given by $\Omega\left(I_{t}, I_{t-1}\right) \equiv\left[1-\Gamma\left(\frac{I_{t}}{I_{t-1}}\right)\right] \times I_{t}$, where $\Gamma(1)=\Gamma^{\prime}(1)=0$ and $\Gamma^{\prime \prime}(1) \equiv \gamma>0 . \quad I_{t}$ is interpreted as private gross investment. In steady state, $I_{t}=I_{t-1}$ and $\Gamma(1)=0$, so gross investment equals net investment. $\delta$ is the depreciation rate of private capital.

We adopt the standard assumption that time-to-build for private capital is one quarter; that is, $I_{t}$ adds to the capital stock $K_{t}$, which is productive at time $t+1$. The sensitivity analysis in section 4 relaxes this assumption and allows for longer time-to-build constraints on private capital.

The economy produces goods according to a Cobb-Douglas technology

$$
Y_{t}=A\left(u_{t} K_{t-1}\right)^{\alpha_{K}}\left(L_{t}\right)^{\alpha_{L}}\left(K_{t-1}^{G}\right)^{\alpha_{G}}
$$

where $K_{t-1}^{G}$ is public capital in place at the end of $t-1, u_{t} K_{t-1}$ is the effective capital stock, and $A$ is a fixed productivity parameter. $\alpha_{G}$ is the elasticity of output with respect to public capital. When $\alpha_{G}=0$, government investment is unproductive.

\footnotetext{
${ }^{5}$ The literature has yet to form a consensus about the most appropriate way to model habit formation. Some assume internal habits [McCallum and Nelson (1999), Amato and Laubach (2004), Christiano, Eichenbaum, and Evans (2005), and Kano and Nason (2008)], while others model habits as external [Abel (1990), Smets and Wouters (2003), Ravn, Schmitt-Grohe, and Uribe (2006)]. However, Dennis (2008) shows that to first-order approximation, the difference between internal and external habits is inconsequential for matching business cycle data.

${ }^{6} \mathrm{~A}$ more natural way to model the cost of increasing capital utilization is to make the depreciation rate depend on the utilization rate [Burnside and Eichenbaum (1996)]. The method we employs helps to identify the capital utilization parameter in estimation [Schmitt-Grohe and Uribe (2007)].
} 
The representative firm, taking prices as given, rents private capital and labor at the rates of $r_{t}$ and $w_{t}$ to maximize per-period profit

$$
Y_{t}-r_{t} u_{t} K_{t-1}-w_{t} L_{t}
$$

2.2. Government. The government sector purchases consumption goods $\left(G_{t}^{C}\right)$ and investment goods $\left(G_{t}^{I}\right)$. Revenue is generated through income taxes and by issuing one-period debt to finance its expenditures, which include government purchases, principal and interest service for debt, and transfers to households. The flow government budget constraint is

$$
\tau_{t}^{K} r_{t} u_{t} K_{t-1}+\tau_{t}^{L} w_{t} L_{t}+B_{t}=G_{t}^{C}+G_{t}^{I}+R_{t-1} B_{t-1}+T_{t}
$$

The aggregate resource constraint is

$$
C_{t}+I_{t}+\psi\left(u_{t}\right) K_{t-1}+G_{t}^{C}+G_{t}^{I}=A\left(u_{t} K_{t-1}\right)^{\alpha_{K}}\left(L_{t}\right)^{\alpha_{L}}\left(K_{t-1}^{G}\right)^{\alpha_{G}} .
$$

2.2.1. Modeling the spending process. We model implementation delays in government investment with a time-to-build specification for public capital. We assume public capital does not become productive for several quarters and that government investment in public capital occurs gradually over time.

Table 1 motivates the time-to-build specification. The table reports the Congressional Budget Office's cost estimates and outlays for two pieces of legislation that involved government investment: the American Recovery and Reinvestment Act (ARRA) of 2009 and the National Highway Bridge Reconstruction and Inspection Act (NHBRIA) of 2008. ${ }^{7}$ The Congressional Budget Office's cost estimates for the ARRA allow for substantial implementation delays in government investment and show that the outlays flow over several years following the authorization. Congress authorized $\$ 27.5$ billion for highway construction in 2009 , yet the estimated outlays are only $\$ 2.75$ billion for 2009 , with a majority of the outlays occurring over the next six years. ${ }^{8}$ Nearly half of the estimated outlays occur after fiscal year 2011. ${ }^{9}$ Another recent example is the NHBRIA, which would have authorized appropriations of about $\$ 1$ billion in fiscal year 2009 for repairing, rehabilitating, and replacing bridges on public roadways. Outlays associated with this legislation would have extended more than four years into the future, as table 1 shows. The estimated first-year outlays account for only 27 percent of the total budget authority, while the cumulative outlays at the end of second year are only about 67 percent.

We model the delay between when government investment is authorized and when it comes on line as public capital by letting the budget authorized for government investment at time $t$ be $A_{t}^{I}$ and the number of quarters to complete an investment project be $N$. The law of motion for public capital is then

$$
K_{t}^{G}=\left(1-\delta_{G}\right) K_{t-1}^{G}+A_{t-N+1}^{I}
$$

\footnotetext{
${ }^{7}$ The NHBRIA bill was not enacted.

${ }^{8}$ This bill includes many transportation projects. The implementation period of eight years does not imply that all projects take eight years to complete, as some projects do not start until later years.

${ }^{9}$ As of May 22, 2009 (three months after the enactment), outlays as a percent of budget authority were less than 1 percent of budget authority on transportation in the ARRA [Elmendorf (2009)].
} 
American Recovery and Reinvestment Act of 2009

\begin{tabular}{llllllllll}
\hline & 2009 & 2010 & 2011 & 2012 & 2013 & 2014 & 2015 & 2016 & $2009-16$ \\
\hline \hline Budget Authority & 27.5 & 0 & 0 & 0 & 0 & 0 & 0 & 0 & 27.5 \\
Estimated Outlay & 2.75 & 6.875 & 5.5 & 4.125 & 3.025 & 2.75 & 1.925 & .55 & 27.5 \\
\hline \hline
\end{tabular}

National Highway Bridge Reconstruction and Inspection Act of 2008

\begin{tabular}{lllllll}
\hline & 2009 & 2010 & 2011 & 2012 & 2013 & $2009-13$ \\
\hline \hline Budget Authority & 1,029 & 5 & 5 & 5 & 5 & 1,049 \\
Estimated Outlay & 280 & 425 & 169 & 56 & 46 & 976 \\
\hline
\end{tabular}

TABLE 1. Top panel: estimated costs in billions of dollars for highway construction in Title XII of the American Recovery and Reinvestment Act of 2009 [Source: Congressional Budget Office, www.cbo.gov/ftpdocs/99xx/doc9989/hr1conference.pdf]. Bottom panel: estimated costs in millions of dollars for the National Highway Bridge Reconstruction and Inspection Act of 2008, Source: Congressional Budget Office, www.cbo.gov/ftpdocs/97xx/doc9764/hr3999.pdf].

where the budget authorization process follows an $\operatorname{AR}(1)$ (in log-linearized form),

$$
\widehat{A}_{t}^{I}=\rho_{I} \widehat{A}_{t-1}^{I}+\varepsilon_{t}, \quad \varepsilon_{t} \stackrel{i i d}{\sim} N\left(0, \sigma_{\varepsilon}^{2}\right) .
$$

Table 1 suggests that the amount of government investment authorized can deviate substantially from the outlays. To capture this, we assume the government investment implemented (or outlaid) at time $t$ is given by

$$
G_{t}^{I}=\sum_{n=0}^{N-1} \phi_{n} A_{t-n}^{I}
$$

where $\sum_{n=0}^{N-1} \phi_{n}=1$. The $\phi$ 's capture the outlay or spending rates of the authorized budget. When $N=1$, the model does not separate budget authority and outlays, and there is no delay in implementing government investment: $\phi_{0}=1$, and $G_{t}^{I}=A_{t}^{I}$.

At time $t$ agents observe the current and past realizations of the innovations to government investment policy $\left\{\varepsilon_{t-j}\right\}_{j=0}^{\infty}$, and know the timing pattern of building public capital. This assumes that information about spending legislation and its estimated outlay paths is publicly available, being widely reported in the press, so that people foresee when a public capital project will be completed. ${ }^{10}$

2.2.2. Debt Financing. Increases in government investment that are initially debt-financed must eventually bring forth adjustments to fiscal policy that ensure solvency. To ensure that a first-order approximation remains valid, the adjustments to transfers, government consumption, or one of the income tax rates are sufficient to return the debt-output ratio to its steady state value. In log-linearized forms, the fiscal rules are

$$
\widehat{T}_{t}=\rho^{T} \widehat{T}_{t-1}+q_{8}^{T} \widehat{s}_{t-8}^{B}, \quad q^{T} \leq 0,
$$

\footnotetext{
${ }^{10}$ It is straightforward to show that this information structure leads to the empirical difficulties described in Ramey (2008) and Leeper, Walker, and Yang (2008, 2009).
} 


$$
\begin{gathered}
\widehat{\tau}_{t}^{L}=\rho^{L} \widehat{\tau}_{t-1}^{L}+q_{8}^{L} \widehat{s}_{t-8}^{B}, \quad q^{L} \geq 0, \\
\widehat{\tau}_{t}^{K}=\rho^{K} \widehat{\tau}_{t-1}^{K}+q_{8}^{K} \widehat{s}_{t-8}^{B}, \quad q^{K} \geq 0,
\end{gathered}
$$

and

$$
\widehat{G}_{t}^{C}=\rho^{C} \widehat{G}_{t-1}^{C}+q_{8}^{C} \widehat{s}_{t-8}^{B}, \quad q^{C} \leq 0,
$$

where $\widehat{s}_{t-8}^{B}$ is the deviation from the steady state debt-output ratio at the end of $t-8 .{ }^{11}$

In the main model, fiscal adjustments are not triggered until eight quarters after the initial increase in government debt. Since the federal government is not subject to year-to-year balanced budget rules, delayed financing is more relevant empirically. ${ }^{12}$

2.3. Calibration. The model is calibrated at a quarterly frequency. Most parameters are set to values that are typical in real business cycle studies of fiscal policy. Table 2 summarizes the parameter values under the benchmark calibration. In steady state the consumptionoutput ratio is 0.64 , the private investment-output ratio is 0.16 , and the share of time devoted to work is 0.2 . We justify the settings of some of the non-standard parameters below.

2.3.1. Public and private capital. We calibrate the ratio of public to private capital at $K^{G} / K=0.32$ in the steady state, which equals the historical U.S. average from 1947-2007 (table 1.1 of Fixed Assets Accounts, BEA). Government investment as a share of output is $s^{G I}=0.04$, which equals the historical average from 1947 to 2007 (NIPA Table 3.9.5). Given $s^{G I}$ and the ratio of public to private capital, the implied depreciation rate for public capital is $\delta_{G}=0.02$, which is comparable to the literature [Baxter and King (1993) and Kamps (2004) set $\left.\delta=\delta_{G}=0.025\right] .^{13}$

To calibrate the production function, (5), we follow Baxter and King (1993) and Glomm and Ravikumar (1997) and assume constant returns to scale with respect to private production factors: $\alpha_{K}+\alpha_{L}=1$.

There are diverse views in the litaerature about the productivity of public capital $\left(\alpha_{G}\right)$. Early work estimates log-linear production functions and tends to find a relatively large $\alpha_{G}$. Aschauer (1989b) obtains the elasticity of output to nonmilitary public capital to be 0.39 , and Aschauer (1989a) finds that the elasticity for core infrastructure (transportation, utility, and water) is $0.24 .{ }^{14}$ Results from subsequent studies using alternative methodologies are

\footnotetext{
${ }^{11}$ Leeper and Yang (2008) adopt similar rules, but assume that the fiscal adjustment is triggered onequarter after the rising debt-output ratio. We examine this alternative in section 4.

${ }^{12}$ Under current PAYGO rules, new mandatory spending or tax policy changes should not add to the deficit; hence fiscal adjustments should occur within a specified budget window. In recent years, however, PAYGO rules have been waived several times.

${ }^{13}$ Based on the data from the current-cost depreciation in the Fixed Assets Accounts (table 1.3), the average annual depreciation rate for government capital is about 0.04 . However, using this depreciation rate will imply too little government investment in the steady state. The data also imply a smaller depreciation rate for public capital than for the private capital. Note that capital in our model implicitly includes durable goods, which have higher depreciation rates.

${ }^{14}$ The production function approach has been challenged on several econometric grounds, in particular, for missing values and causality problems. See Munnell (1992) and Gramlich (1994) for a survey and the criticisms. Recent work by Kamps (2004) estimates VARs for 22 OECD countries and finds evidence that GDP Granger causes public capital, suggesting reverse causation as assumed when estimating a log-linear production function.
} 
inconclusive about the productivity of public capital. Holtz-Eakin (1994), using state-level data, finds that public-sector capital has no effect on private sector productivity. Evans and Karras (1994), using panel data for 48 states from 1970 to 1986, find that government capital often has statistically significant negative productivity. Kamps (2004) estimates structural VARs to find that an exogenous increase in public capital has no significant effects on output for the U.S. In contrast to these negative results, Nadiri and Mamuneas (1994) obtain significant productive effects from infrastructure and R\&D capital in terms of the cost structure and productivity performance of 12 two-digit U.S. manufacturing industries. Pereira and de Frutos (1999) estimate the elasticity of private output with respect to public capital to be between 0.34 and 0.39 for U.S. data from 1956 to 1989 .

Given the wide range of estimates for $\alpha_{G}$, we explore $\alpha_{G}=0.05$ (the benchmark value used in Baxter and King (1993)) and $\alpha_{G}=0.1$. Under our benchmark calibration, with $\alpha_{K}=0.36$ and $K^{G} / K=0.32, \alpha_{G}>0.12$ implies that the marginal product of public capital is greater than the marginal product of private capital in the steady state. We set the upper bound for $\alpha_{G}$ to be 0.1 .

2.3.2. Fiscal variables. The government consumption share of output in the steady state is set to its historical average, $s^{G C}=0.16$ (1947-2007, NIPA table 3.9.5). Steady-state tax rates on capital and labor income are set to the average tax rates from 1947 to 2007 as constructed by Jones's (2002) method. We select the transfer-output ratio $s^{T}=0.058$ so that the debt-output ratio is $s^{B}=1.66$ in the steady state. ${ }^{15}$

To calibrate implementation delays, we refer to a Congressional Budget Office (2008, p. 19) report that states: "... for major infrastructure projects supported by the federal government, such as a highway construction and activities of the Army Corps of Engineers, initial outlays usually total less than 25 percent of the funding provided in a given year. For large projects, the initial rate of spending can be significantly lower than 25 percent." We assume the maximum period to complete a government investment project is three years, so $N=12$ in equation (11). The spending rates in table 2 , the $\phi$ 's, are for $N=12$. During the initial quarter when a bill is enacted, we assume zero outlay because of the administrative and planning process involved in an investment project. With three-year time-to-build, at the end of first year 25 percent of the authorized budget is spent $\left(\phi_{0}=0\right.$ and $\left.\phi_{1}=\phi_{2}=\phi_{3}=0.083\right)$; by the end of the second year, two thirds of the authorized budget is spent; the rest is spent during the third year. The analysis also explores two other spending patterns, which take one year to complete $\left(N=4, \phi_{0}=0\right.$, and $\left.\phi_{1}=\ldots=\phi_{4}=1 / 3\right)$ and one-quarter to complete $\left(N=1\right.$ and $\left.\phi_{0}=1\right)$.

Our study of the effects of fiscal adjustment methods, allows only one fiscal instrument to adjust at a time. The choices of steady-state fiscal adjustment parameters, $q$ 's in table 2 , yield a pattern of debt responses to a government investment shock that roughly follows the paths estimated from U.S. data. Under the benchmark calibration, the half life of the debt-output ratio is about 81 to 83 quarters in response to a 1 percent government investment shock,

\footnotetext{
${ }^{15}$ The average ratio of federal debt held by the private sector to annual GDP is 0.42 from 1947 to 2007 [table B79, Economic Report of the President (2009)]. This implies that the ratio of debt to quarterly GDP is 1.68 .
} 


\begin{tabular}{|lr|lr|lr|}
\hline Parameter & Value & Parameter & Value & Parameter & Value \\
\hline$\alpha^{K}$ & .36 & $\tau^{L}$ & .21 & $\psi^{\prime \prime}(1) / \psi^{\prime}(1)$ & .18 \\
$\alpha^{L}$ & .64 & $\tau^{K}$ & .39 & $A$ & 1 \\
$\alpha^{G}$ & {$[.05,0.1]$} & $s^{T}$ & .07 & $\gamma$ & 2 \\
$\delta$ & .025 & $s^{G I}$ & .04 & $\rho^{I}, \rho^{K}$ & .9 \\
$\delta_{D}$ & .02 & $s^{G C}$ & .16 & $\phi_{0}$ & 0 \\
$e, \theta$ & 2 & $q_{8}^{T}$ & -.007 & $\phi_{1} \sim \phi_{3}$ & .083 \\
$b$ & .25 & $q_{8}^{L}$ & .004 & $\phi_{4} \sim \phi_{7}$ & .105 \\
$\chi$ & 6.63 & $q_{8}^{K}$ & .03825 & $\phi_{8} \sim \phi_{11}$ & .083 \\
$\beta$ & .99 & $q_{8}^{C}$ & -.0035 & $\rho^{T}, \rho^{C}, \rho^{L}$ & .98 \\
\hline
\end{tabular}

TABLE 2. Benchmark calibration. The spending rates $\phi$ 's are the values for three-year delay in implementing government investment $(N=12)$.

and the peak increase in the debt-output ratio ranges from 0.17 to $0.19{ }^{16}$ Friedman (2005) finds that the half life of the debt-output ratio responses to its own shock in a univariate autoregressive representation is 85 quarters for the postwar U.S. data.

To compute multipliers, we allow for all fiscal instruments to adjust, with the weights assigned to each instrument based on empirical estimates. Leeper, Plante, and Traum (2009) use Bayesian methods to estimate federal fiscal multipliers in U.S. data from 1960-2008. They find that data prefer a model that allows all financing methods - government spending, transfer, and capital and labor income taxes - to respond to debt. The estimates suggest that historically the government has relied more on adjusting transfers and capital income taxes to stabilize debt and less on government spending and labor income taxes. The weights are $0.44,0.33,0.19$, and 0.04 for transfers, capital taxes, government consumption, and labor taxes, respectively. ${ }^{17}$

2.3.3. Friction parameters. Finally, we calibrate parameters governing habit formation, investment adjustment costs, and the capital utilization rate adopting values estimated in DSGE models. Bouakez and Rebei (2007) estimate a model with a similar functional form for the habit stock, obtaining the degree of habit formation $b=0.25$. The cost parameter for investment adjustments is set to $\gamma=2$, consistent with Christiano, Eichenbaum, and Evans (2005). The cost parameter for increasing capital utilization rate is set to $\frac{\psi^{\prime \prime}(1)}{\psi^{\prime}(1)}=0.18$, as estimated by Smets and Wouters (2003). A higher value of $\frac{\psi^{\prime \prime}(1)}{\psi^{\prime}(1)}$ indicates higher costs from increasing the utilization rate above its steady state value. When $b=0, \gamma=0$ and $\frac{\psi^{\prime \prime}(1)}{\psi^{\prime}(1)}$ is set to a high value (like 2), the model's performance when lump-sum transfers adjust to stabilize debt approaches that of simple neoclassical growth models, as in Baxter and King (1993) and Kamps (2004).

\footnotetext{
${ }^{16}$ We define half life as the time it takes for the peak response of debt to a government spending shock to decay by 50 percent.

${ }^{17}$ Fiscal rules estimated in Leeper, Plante, and Traum (2009) are slightly different from those used here. They assume that government responds to deviations in the level of debt, not the debt-output ratio and the response lag is only one quarter.
} 


\section{Impacts of Government Investment}

Proponents of increasing government investment often argue that productive government investment can boost employment in the short run and promote economic growth in the long run. ${ }^{18}$ That outcome is supported by a conventional neoclassical growth model with productive public capital, which predicts that an unexpected increase in government investment can generate higher employment and output at both short and longer horizons [Baxter and King (1993)]. These positive results, however, hinge on structures that do not account for implementation delays and distorting offsetting policies.

We begin with a simplified version of the main model, where the setup is the same as in section 2, except that only lump-sum taxes (or reductions in lump-sum transfers) are used to balance the budget each period. We first show that with no implementation delays and lump-sum financing, our model produces the same qualitative responses to a government investment shock for key macroeconomic variables as those obtained from conventional neoclassical growth models. Because implementation delays affect short-run dynamics in a similar manner across various financing methods, we then continue to use the simplified model to illustrate the impact of implementation delays. Finally, we show that distorting fiscal adjustments are important for both long and short-term effects under the four financing mechanisms described in section 2 .

3.1. Effects with No Implementation Delays and Lump-Sum Financing. Neoclassical growth models capture three important channels that determine the impact of government investment: the crowding-out effect, wealth effects (both negative and positive), and the effect from changing the marginal productivity of private inputs. Ceteris paribus, higher government investment reallocates existing resources so there are fewer goods available for the private sector to consume and save. This crowding-out effect is induced by more competition for goods from higher government demand. As goods today become more valuable, the real interest rate rises to clear the goods market. Higher government investment financed by lump-sum taxes generates a negative wealth effect, encouraging agents to work harder and save more by reducing consumption. ${ }^{19}$ When government investment is productive, however, there is another wealth effect in the opposite direction: a higher stock of productive public capital acts like a total factor productivity increase to create the expectation that more goods will be available in the future. This discourages current saving. Finally, the last effect occurs at longer horizons as public capital gradually builds up, which increases the marginal product of capital and labor. This provides incentives to work and save due to higher wages and returns to capital.

Figure 1 shows the impacts of an increase in government investment under three different assumptions about the productivity of public capital: dotted lines assume $\alpha^{G}=0.1$, solid

\footnotetext{
${ }^{18}$ Aschauer's (1989b) work provides empirical links between productive public capital and private productivity. Aschauer (1990) emphasizes the growth effect of government investment, arguing that non-military investment spending is expansionary. Recent policy discussions focus on the ability of government investment to create jobs in the short run [Federal Highway Administration (2002) and Romer and Bernstein (2009)].

${ }^{19}$ The literature studying the effects of unproductive government spending often combines the crowdingout effect with the negative wealth effect, because both reduce consumption and increase labor. But the two effects have different implications for private investment. The crowding out effect lowers investment, but the negative wealth effect creates an incentive to increase investment (saving).
} 

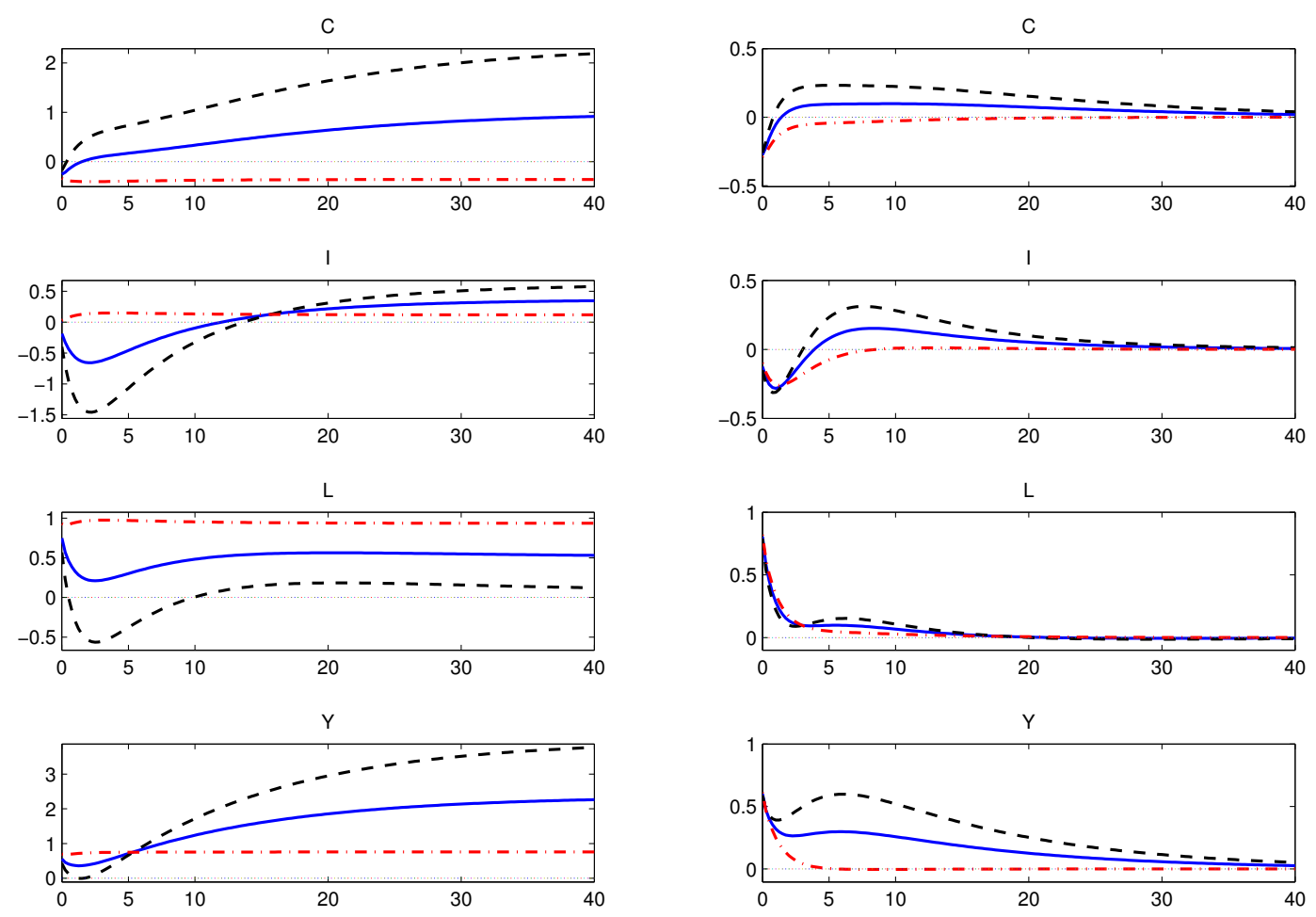

Figure 1 a: Permanent shock to $G$

Figure 1 b: Temporary shock to $G$

FIGURE 1. Impulse responses to government investment shocks with no implementation delays and lump-sum financing. Dotted-dashed lines: $\alpha^{G}=0$; solid lines: $\alpha^{G}=0.05$; dashed lines: $\alpha^{G}=0.1$. All consumption, investment, and output responses are in terms of goods units. Labor is in percent deviation from the steady state level. The $x$-axis is years after the shock.

lines assume $\alpha^{G}=0.05$, and dotted-dashed lines assume $\alpha^{G}=0$. The first column reports responses to a permanent shock of government investment $\left(\rho^{I}=1\right)$, and the second column reports responses to a transitory shock $\left(\rho^{I}=0.9\right)$. Other parameters are set to those in table 2 .

As shown by the first column in the figure, a permanent increase in unproductive government investment (dotted-dashed lines), produces a dominant negative wealth effect. Agents reduce consumption, increase saving (investment), and work more. Consequently, government spending stimulates output but lowers both consumption and leisure. ${ }^{20}$ However, if government investment is productive, private investment can drop substantially in the short run due to the positive wealth effect from the higher expected future productivity created by the increase in the stock of public capital. With productive government investment, consumption is permanently higher while labor is also higher because more public capital raises

\footnotetext{
${ }^{20}$ This is often referred to as the "neoclassical view" of government spending, as examined by Barro (1989). Gali, Lopez-Salido, and Valles (2007) and Monacelli and Perotti (2008) argue that the crowding out of private consumption is inconsistent with vector autoregressive evidence and propose creative modeling techniques to reconcile theory with the VAR evidence.
} 
the marginal product of labor. Comparing responses under $\alpha^{G}=0.1$ and 0.05 , we find that the more productive is government investment, the stronger is the positive wealth effect, which generates greater initial declines in private investment and smaller increases in labor. For investment, employment, and output the short-run impacts can differ markedly from the long-run effects.

A transitory $\left(\rho_{I}=0.9\right)$ government spending shock elicits somewhat different responses, as shown in the second column of figure 1. While output remains positive, unlike permanent government investment increases, private investment falls initially, regardless of the value of $\alpha^{G}$. Investment adjustment costs generate a hump-shaped decline in investment because adjustment costs punish rapid changes. When a government investment shock is transitory, the two opposite wealth effects from higher future lump-sum taxes and higher future income become weaker. In the short run, the crowding-out effect dominates, lowering both consumption and saving. As the productive public capital stock gradually accumulates, private investment eventually rises in response to the resulting increase in the productivity of private capital.

It may seem surprising that enhanced productiveness of public capital generates larger initial declines in private investment. Private investment falls by 0.15 units when $\alpha^{G}=0.1$, by 0.15 units when $\alpha^{G}=0.05$, and by 0.10 units when $\alpha^{G}=0$. This difference arises because the larger $\alpha^{G}$ produces a stronger positive wealth effect, which raises the consumption profile at the expense of saving. The peak initial decline in consumption is the smallest when $\alpha_{G}=0.1$.

This model predicts immediate and sustained increases in labor and output whether government spending is productive or unproductive. The channels through which labor and output increase, however, are quite different: with unproductive government spending the main channel is a negative wealth effect, while for productive government investment the primary channel is the resulting increase in the productivity of private inputs. In either case, the results provide some support for the use of government spending or government investment to expand employment and output. Now we turn to how these results change when government investment is subject to implementation delays and distorting fiscal financing.

3.2. Implementation Delays: Time-to-Build Public Capital. Because permanent increases in government investment are rare, we shift the focus to transitory increases. Implementation delays mainly affect short-run responses. To illustrate the impacts of implementation delays, we assume public capital is subject to a time-to-build lag. We continue to assume lump-sum financing.

Figure 2 plots responses to an exogenous government investment shock for $\alpha^{G}=0.1$ (first column) and $\alpha^{G}=0.05$ (second column). The figure reports results for three different lengths between when the budget for an investment project is authorized and when the project is completed: one quarter ( $N=1$, dashed lines); one year $(N=4$, dotted-dashed lines); three years ( $N=12$, solid lines). Implementation periods up to a year apply to maintenance projects for existing infrastructure or new smaller projects, while a three-year delay applies to large infrastructure projects, such as a dam or a new interstate highway. To facilitate comparison, we repeat the responses with no implementation delays $(N=1$, as seen in the previous section). In addition, we scale the responses so that the area under the three 

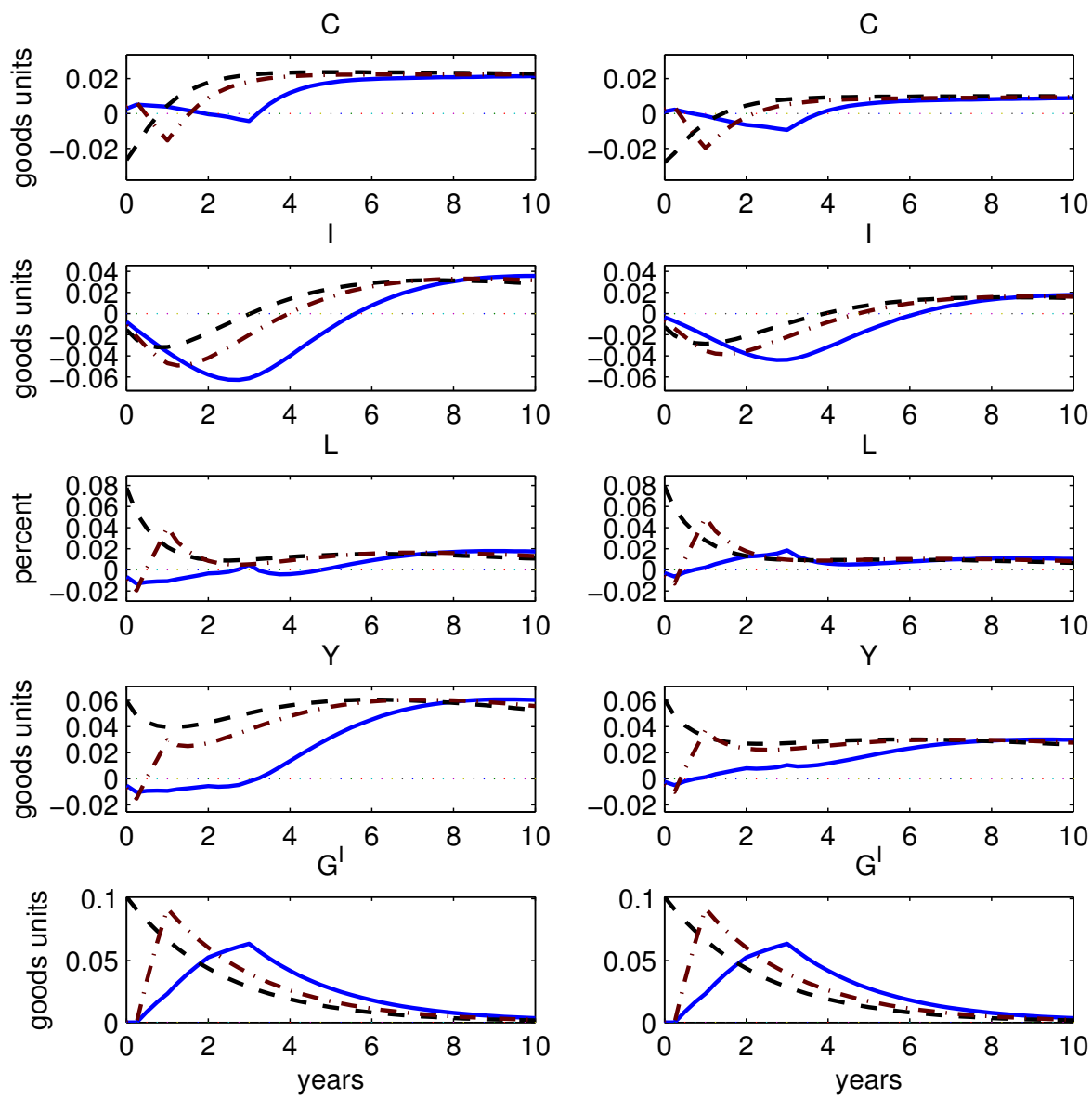

FiguRE 2. Impulse responses to higher government investment with implementation delays. First column: $\alpha_{G}=0.1$; second column: $\alpha_{G}=0.05$. Dashed lines: one-quarter delay; dotted-dashed lines: one-year delay; solid lines: threeyear delay. The area under $G^{I}=1$ for all scenarios. All consumption, investment, and output responses are in terms of goods units. Labor is in percent deviation from the steady state level.

curves of government investment equals one unit of good [bottom two panels of the figure]. All consumption, investment, and output responses are in terms of goods units and are interpretable as multipliers. Labor is in percent deviation from the steady state level.

Implementation delays alter the short-run dynamics substantially, especially for consumption, labor, and output. As shown earlier, under the usual assumption of no delays (dashed lines), consumption and private investment fall but output and labor rise immediately. Private investment does not rise until more than three years after the shock.

When there are implementation delays, private investment does not rise until much later: after four years with one-year delay and almost six years with three-year delay. The peak decline is also larger than in the case without delays. Implementation delays imply a slower 
build-up of public capital, and, therefore, a slower increase in the marginal product of private inputs. Because it takes less time to build private capital, agents postpone investment until the public capital stock is usable.

While investment responses differ only quantitatively when there are implementation delays, consumption, labor, and output differ qualitatively in their short-run dynamics. As in the earlier model, the driving force for an immediate increase in labor without delay is the crowding-out effect or negative wealth effect. Under implementation delays, the government absorbs fewer goods initially and the crowding out effect is smaller in the short run. On the other hand, since the total increase in government investment is the same across the three delay periods, the positive wealth effect from higher future public capital operates in each case. Less crowding out each period, coupled with the same positive wealth effect, generates a slight decline in employment and a slight increase in consumption in the short run, in contrast to the case without delays.

With implementation delays, labor also declines in the short run because the marginal product of labor rises only gradually as public capital gets installed. With longer implementation delays, the rebound in investment and labor is also slower. Consequently, with a three-year delay, output does not begin to rise until three years after the shock; with a one-year delay, output does not rise until two quarters after the shock.

When $\alpha^{G}=0.05$ (second column of figure 2), the qualitative patterns of all variables follow closely to those with $\alpha^{G}=0.1$. Under $\alpha^{G}=0.05$, the initial decline in labor and output under delayed implementation is, however, negligible. As public capital is less productive, the positive wealth effect induced from more productive public capital is also smaller. When $\alpha^{G}=0.05$ and $N=4$ or $N=12$, this positive wealth effect is almost canceled out entirely by the crowding-out effect, leaving little impact on consumption, labor, and output for the initial two to three quarters. Since public capital is less productive, the subsequent increase of private investment and labor is also smaller because the productivity of private inputs rises less.

The above analysis shows that an implementation delay is qualitatively and quantitatively important for short-run dynamics. In contrast to the results when there is no implementation delay - that an increase in government investment is expansionary and raises employment immediately - we find that implementation delays imply that productive government investment can have little effect or even a negative effect on labor and output in the short run. This period can be as brief as a couple of quarters or as long as three years. In addition, the short-run decline in private investment can be larger and longer compared to the case without implementation delays. These results demonstrate the importance of incorporating implementation delays in when assessing the short-term effects of government investment.

3.3. Fiscal Adjustments. Another important consideration to determine the effects of government investment, particularly in the long run, are the sources of fiscal financing. Up to this point, we exploited the Ricardian equivalence of the model when government spending is financed by non-distorting taxes. Of course, government typically finances stimulus packages by selling government debt, most of which is ultimately financed by distorting fiscal instruments. We examine four alternative schemes for financing and eventually retiring the expansion in new debt: adjustments to future lump-sum transfers, unproductive government 

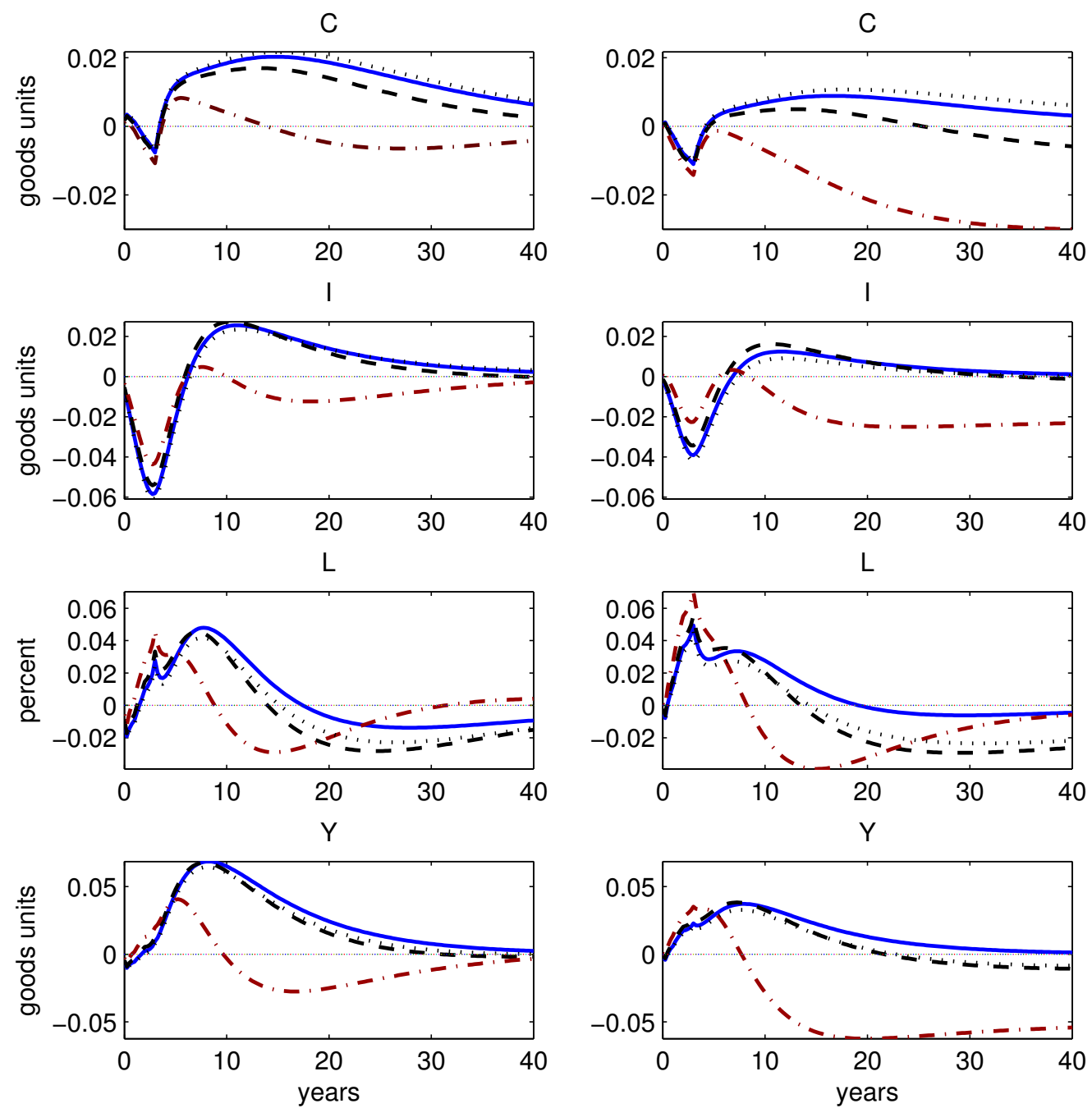

FIGURE 3. Impulse responses to higher government investment under various financing methods. Solid lines: transfers adjust; dashed lines: labor income taxes adjust; dotted-dashed lines: capital income taxes adjust; dotted lines: government consumption adjust. First column: $\alpha^{G}=0.1$; second column: $\alpha^{G}=0.05$. The total increase of government investment is 1 unit of goods in all scenarios.

spending, capital taxes, and labor taxes. In addition, we examine the speed at which debt is paid back. Because time-to-build assumptions have little influence on responses at the longer-run horizon, we illustrate how fiscal adjustments matter for the government investment effects assuming three years to build for public capital.

3.3.1. Adjustment Method. Fiscal adjustment parameters are set to the values in table 2 . Figure 3 plots responses for each of the four financing schemes: solid lines assume lumpsum transfers adjust, dashed lines assume labor income taxes adjust, dotted-dashed lines 
assume capital income taxes adjust, and dotted lines assume government consumption adjust. The first column has responses under $\alpha^{G}=0.1$, and the second one has responses under $\alpha^{G}=0.05$. As the figure makes evident, the choice of financing instrument matters a great deal for the effects of infrastructure spedning in the long run.

Fiscal adjustments through distorting financing methods create another channel that influences the impacts of government investment. Raising income tax rates or reducing government consumption offsets some of the growth effects from higher productive public capital. The net effect over longer horizons can be expansionary or contractionary. Among the four methods of financing, government investment is most expansionary when non-distorting transfers are reduced (solid lines), and it is least expansionary - in fact, contractionarywhen government raises the tax rate on capital income (dotted-dashed lines). As shown in the path of private investment, raising the marginal tax rate on capital income generates strong negative impacts on private investment. These negative effects can dominate the positive impacts from more productive public capital. Lower private investment also reduces the marginal product of labor, driving down employment. Combining these two factors, output falls below its initial level eight to nine years after the initial government investment shock and stays persistently low before returning to the steady state. $^{21}$

Increasing the tax rate on labor income to stabilize debt reduces the after-tax return to labor, which drives down labor inputs and output relative to the case with transfer reductions. A reduction in (unproductive) government consumption, lowers the amount of resource government absorbs from the economy and offsets some of the crowding out effects from the increase in government investment. As a result, labor falls more and consumption rises relative to the case with transfer reductions. Lower labor, in turn, reduces some of the growth effect from the productive government investment. ${ }^{22}$

As shown in the second column of figure 3, the less productive is government investment (smaller $\alpha^{G}$ ), the more likely government investment is to be contractionary in the longer run. In the extreme case $\alpha^{G}=0$ (not shown here), output turns significantly negative for all three distorting financing methods and is expansionary only when transfers adjust.

3.3.2. Speed of adjustment. Just as the method to finance government investment can have significant impacts on macro aggregates, so can the timing of the financing. Even productive government investment can have anemic effects in the short run if the debt used to finance the government expenditure is assumed to be retired quickly. Figure 4 plots responses to a government investment shock assuming no implementation delays, that $\alpha_{G}=0.1$, and that capital taxes adjust to satisfy the budget constraint. We assume two alternative fiscal rules given by

$$
\begin{aligned}
& \hat{\tau}_{t}^{K}=0.985 \hat{\tau}_{t-1}^{K}+0.007 \hat{s}_{t-8}^{B} \\
& \hat{\tau}_{t}^{K}=0.05 \hat{\tau}_{t-1}^{K}+0.445 \hat{s}_{t-1}^{B} .
\end{aligned}
$$

The first rule, (16), assumes capital taxes only respond to debt two-years out and delivers a half-life of debt of 30 years (solid line), slower than our benchmark calibration of about 20

\footnotetext{
${ }^{21}$ As Leeper and Yang (2008) show, deleterious effects of future fiscal adjustments become more pronounced the more persistent is the initial fiscal disturbance.

${ }^{22}$ Section 4 explores the case where government consumption generates utility.
} 

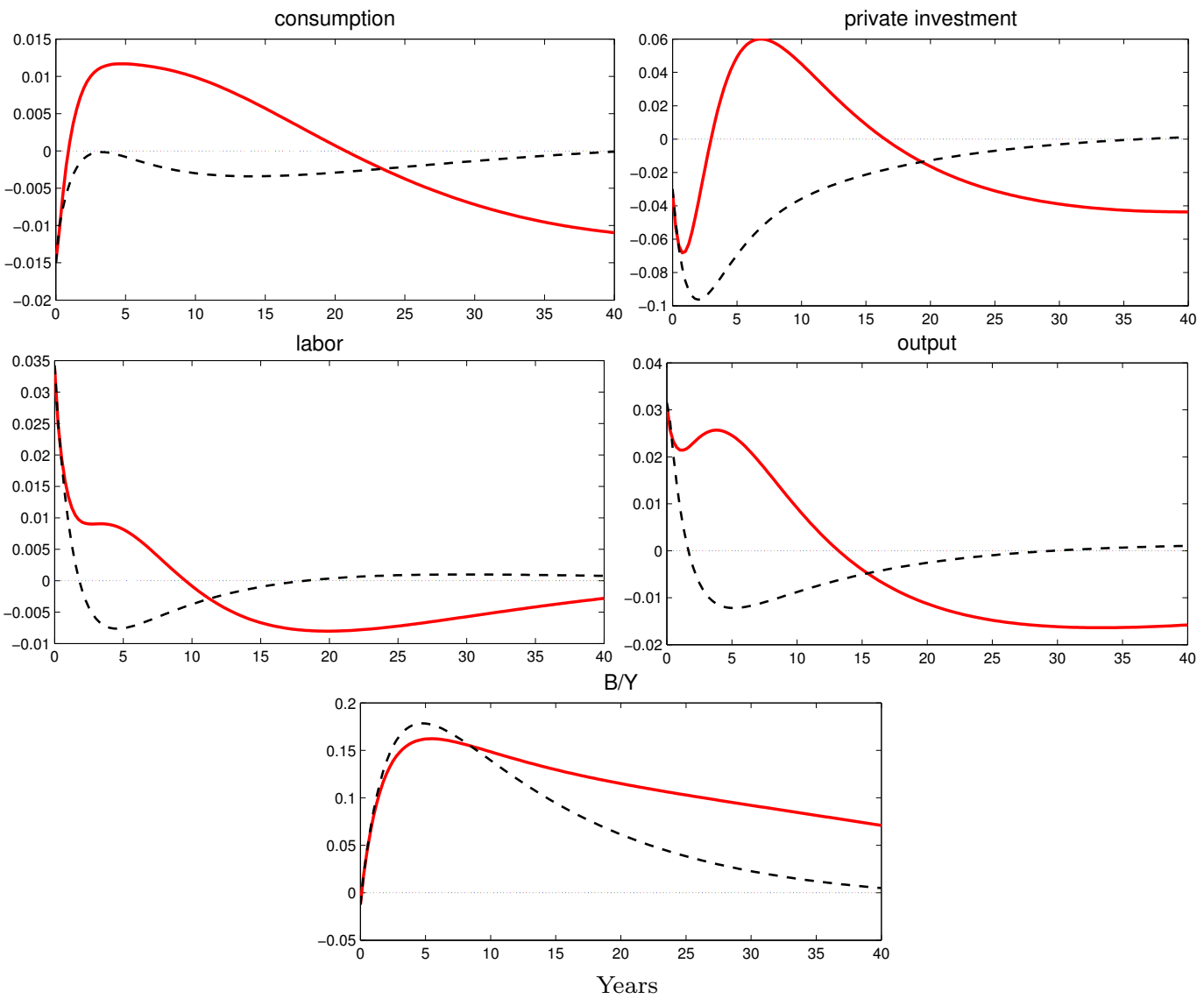

FIGURE 4. Impulse responses to higher government investment with capital taxes adjusting slowly (solid line) according to (16) and quickly according to (17) (dashed line). Assuming no implementation delays and $\alpha^{G}=0.1$.

years. The second rule assumes capital taxes adjust quickly to retire debt, responding with only a one-quarter delay. This rule delivers a half life of debt of 11 years (dashed line).

In general, when an offsetting policy is distorting, speeding up debt retirement enhances the negative impact of fiscal adjustments from raising tax rates or reducing government consumption. Under implementation delays, retiring debt more quickly can slightly amplify the negative effects on labor and output in the short run. With no implementation delays, the differences between a slow and a fast debt retirement can be more conspicuous. Figure 4 demonstrates that the timing of fiscal adjustments can generate both quantitative and qualitative changes in a response to a government investment increase. Under the assumption that debt is retired quickly, consumption and private investment never rise following an increase in government investment. This is because after only one quarter of debt buildup, capital taxes respond aggressively to draw down debt. Higher capital taxes offset the positive wealth effect, reducing consumption, and they lower the after-tax return to capital, significantly depressing investment at all horizons. With respect to the stimulative effects of government investment, notice that output and labor turn negative after only one year under 
the quick adjustment specification. This suggests that the stimulative effects of government spending depend crucially on the timing of fiscal adjustments.

\section{Sensitivity Analysis: Alternative Model Specifications}

In this section we check the robustness of our conclusions along three dimensions. Our analysis so far has assumed that government consumption is unproductive. Following the literature in studying the relationship between government and private consumption, we allow government consumption to be a complement or a substitute with private consumption. Second, we have assumed time-to-build for government investment based on an institutional argument, but not for private capital. Since the time-to-build assumption is initiated to model the construction process for capital in general, we explore the case where private capital is subject to one year to build. Finally, we model the government sector separately from the private sector, requiring government to hire labor and use intermediate goods to produce its output.

4.1. Utility from Government Consumption. Following Bouakez and Rebei (2007), the agent derives utility from leisure $\left(1-L_{t}\right)$ and effective consumption $\left(\widetilde{C}_{t}\right)$, which is assumed to be a constant-elasticity-of-substitution index of private consumption $\left(C_{t}\right)$ and government consumption $\left(G_{t}^{C}\right)$, as given by

$$
\widetilde{C}_{t}=\left[\varphi C_{t}^{\frac{v-1}{v}}+(1-\varphi)\left(G_{t}^{C}\right)^{\frac{v-1}{v}}\right]^{\frac{v}{v-1}} \text {, with } 0 \leq \varphi \leq 1, v>0 .
$$

When $\varphi=1$, effective consumption collapses to $C_{t}$, and we are back to the model in section 2. $v$ is the elasticity of substitution between private and government consumption: $v=0$ indicates private and government consumptions are perfect complements; $v \rightarrow \infty$ implies that the two are perfect substitutes. Preferences take the form

$$
U_{t} \equiv \frac{1}{1-e}\left(\frac{\widetilde{C}_{t}}{\widetilde{C}_{t-1}^{b}}\right)^{1-e}+\chi \frac{\left(1-L_{t}\right)^{1-\theta}-1}{1-\theta} .
$$

We set the weight on private consumption to be $\varphi=0.8$ as in Bouakez and Rebei (2007). They estimate a DSGE model with the utility function in (19) using U.S. data, and find that the elasticity of substitution between private and government consumption is $v=0.33$. When $e=2$, as in our benchmark calibration, $v<\frac{1}{e}$, which implies Edgeworth complementarity between private and government consumption.

Figure 5 plots impulse responses for $v=0.33$ and $\alpha^{G}=0.1$ under two financing methods: solid lines assume transfers adjust and dotted lines assume government consumption adjusts. The first column assumes three years to build for public capital, and the second column makes the usual assumption of one quarter to build (or no implementation delays). Again, the total increase in government investment under the four scenarios is one unit of goods. Comparing the results from the main model (where government consumption generates no utility) with those from the current model (where government consumption generates utility), we find responses of four macro variables are very similar under adjustments in transfers and the 

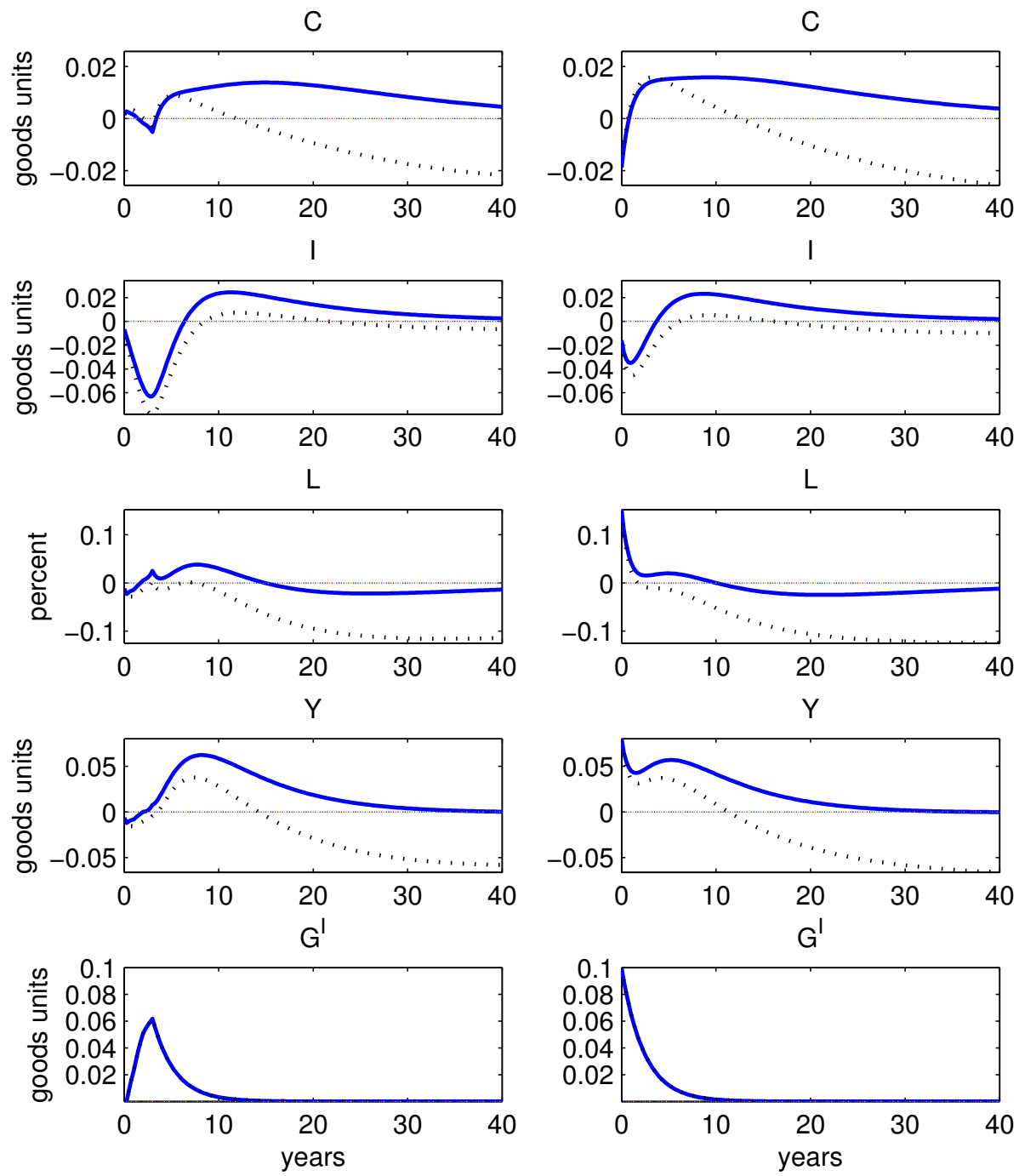

FiguRE 5. Impulse responses to higher government investment when government consumption is a complement to private consumption. Solid lines: transfers adjust; dashed lines: government consumption adjust. First column: three years to build public capital; second column: no implementation delays.

two income tax rates. ${ }^{23}$ For presentation clarity, we only plot results under transfers and government consumption adjustments in figure 5 .

When the fiscal adjustment reduces government consumption, private consumption rises in most periods, in contrast to the case with unproductive government consumption. Output also falls over longer horizons, as does employment for most periods.

\footnotetext{
${ }^{23}$ The two models differ in the value of $\varphi$ and $q^{C}$. We change the benchmark value of $q^{C}=-0.0035$ to $q^{C}=-0.006$ in the current model in order to yield a valid solution. When an adjusting magnitude is too small, the debt-to-output ratio cannot be stabilized, and the transversality condition for debt is violated.
} 
When government and private consumption are complements, a decrease in government consumption reduces the marginal utility derived from private consumption, reducing the incentive to consume. In the previous case when $\varphi=1$, a reduction in government consumption offsets the crowding-out effect from higher government investment, which drives up private consumption. In the current case $(\varphi=0.8$ and $v=0.33)$, private consumption co-moves with government consumption. A decrease in private consumption demand makes labor fall and output fall in the out years despite higher private investment.

Comparing the first column with the second column in figure 5, we find that implementation delays make the short-run expansionary effects of government investment on employment and output as in the main model. Whether under transfers or government consumption adjustments, government investment makes employment and output rise immediately when there are no implementation delays, but these two variables fall in the short run with a three-year delay. In fact, when government consumption generates utility and it is adjusted to stabilize debt, government investment is only expansionary for a relatively short period (about six years with implementation delays and about ten years with no delays) throughout the horizon.

Given the uncertainty about the relationship between private and government consumption in the literature, we also investigate the case where government and private consumption are Edgeworth substitutes by setting $v=0.6 .^{24}$ The responses for all variables under the four methods of fiscal adjustments are very close to those in figure 3 and hence are not shown here. If government consumption is a substitute for private consumption, reductions in government consumption (to reduce deficits) make private consumption rise, reinforcing the crowding-out effect in the case of unproductive government consumption.

Some authors justify treating government and private consumption as complements because it generates positive co-movement in government and private consumption [Bouakez and Rebei (2007)], as in the VAR evidence [Blanchard and Perotti (2002) and Gali, LopezSalido, and Valles (2007)]. Although the literature has not settled on theoretical grounds to explain why private consumption rises following a government spending increase, our conclusion that government investment impacts depend on implementation delays and fiscal adjustments holds up, whether government consumption is unproductive, or is a complement or a substitute with private consumption.

4.2. Time-To-Build for Private Capital. Kydland and Prescott (1982) incorporate timeto-build for construction of all new productive capital to explain the autocovariances of real output and the covariances of cyclical output with other macro variables. To this point, we have assumed time-to-build for public capital but not for private capital. This raises a concern that our results of little or negative output and labor responses to a government investment shock initially may be due to the asymmetric treatment of time-to-build. In this subsection, we extend our main model to allow one year to build for private capital as assumed in Kydland and Prescott (1982) and McGrattan (1994).

\footnotetext{
${ }^{24} \mathrm{~A}$ common specification assumes government and private consumption are additive in a utility function. Estimations under this specification is also inconclusive about whether government consumption and private consumption are Edgeworth substitutes or complements [Kormendi (1983), Aschauer (1985), Ahmed (1986), Karras (1994), and Ni (1995)].
} 

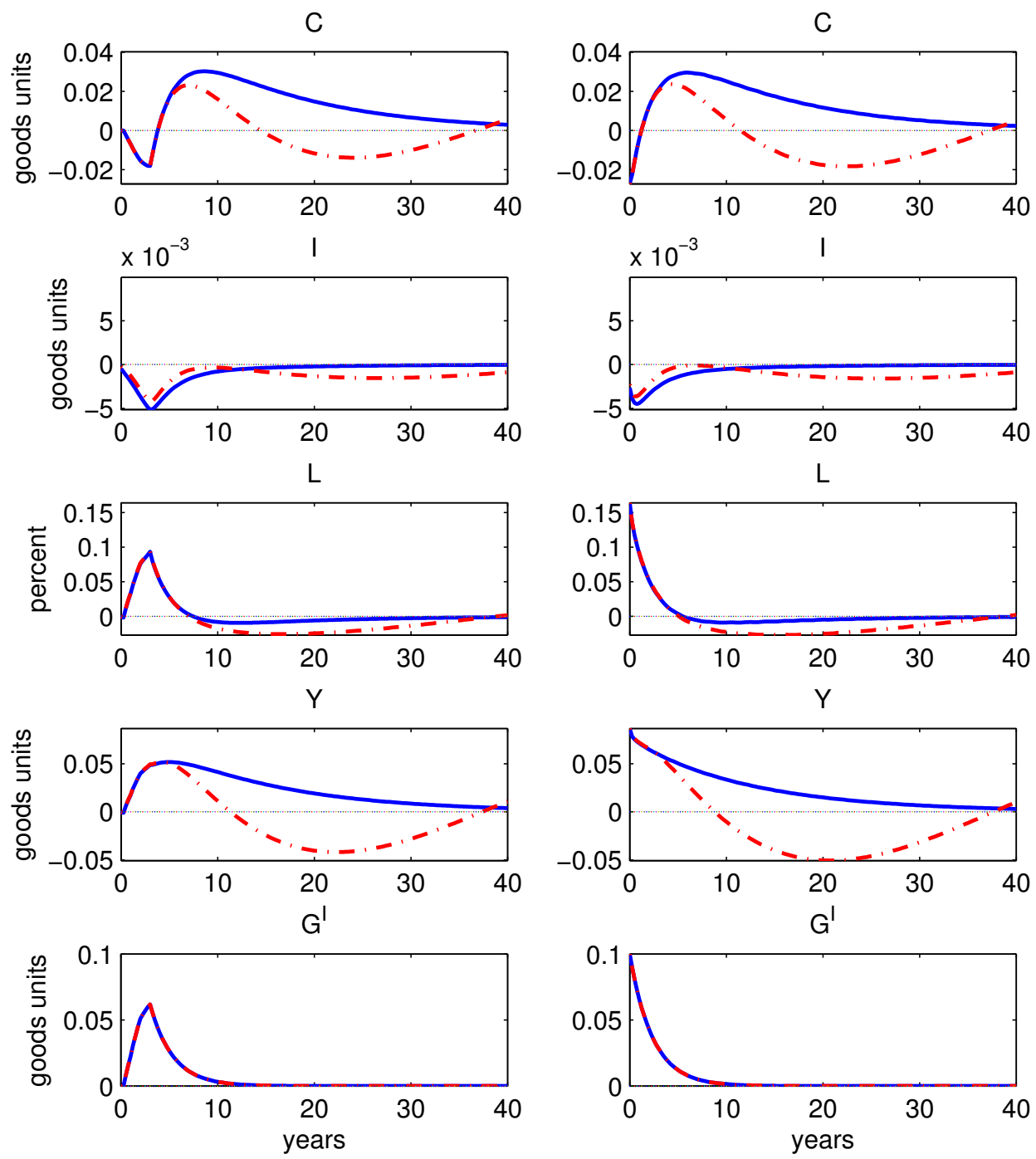

FIGURE 6. Impulse responses to higher government investment with time-tobuild for private capital. Solid lines: transfers adjust; dotted-dashed lines: capital income taxes adjust. First column: three years to build public capital; second column: no implementation delays.

Let $S_{t}$ be in the investment project started at $t$, which takes four quarters to construct and form private capital. The law of motion for private capital is

$$
K_{t}=(1-\delta) K_{t-1}+S_{t}
$$

At time $t$, the fraction of investment project $S_{t}$ implemented is $\phi_{0}^{S}$, and $\phi_{1}^{S}, \phi_{2}^{S}$, and $\phi_{3}^{S}$ are the fractions implemented in dates $t+1, t+2$, and $t+3$. At any given date, implemented 
investment is

$$
\sum_{t=0}^{3} \phi_{i}^{S} S_{t-i}=\Omega\left(I_{t}, I_{t-1}\right), \quad \sum_{t=0}^{3} \phi_{i}^{S}=1,
$$

where $\Omega\left(I_{t}, I_{t-1}\right)$ is net investment excluding adjustment costs and the gross investment cost is $I_{t}$. The rest of the model economy is the same as the setup in section 2 .

To calibrate the time-to-build parameters, we turn to empirical estimates for these parameters. Kydland and Prescott (1982) assume all tangible capital has an average construction period of one year with equal rates for each quarter, but empirical findings reject this assumption. McGrattan (1994) fits a DSGE model with U.S. data from 1947 to 1987 and estimates $\phi_{0}^{S}=0.475, \phi_{1}^{S}=0.0433, \phi_{2}^{S}=0.0683$, and $\phi_{3}^{S}=0.4134$. These parameters are estimated with high precision, but the M-shaped pattern is counterintuitive. Normally, we expect decaying completing rates over time. Montgomery (1995) estimates the value-weighted average completion pattern for U.S. nonresidential structures (1961-1991) and finds a high initial completion rate followed by a slow decaying pattern, with the average construction period of 16.7 months. Figure 6 contains impulse responses with $\phi_{i}^{S}$ 's set to the values McGrattan estimates. We also compute impulse responses using the alternative pattern $\phi_{0}^{S}=0.45$, $\phi_{1}^{S}=0.30, \phi_{2}^{S}=0.15$, and $\phi_{3}^{S}=0.1$. The results are very close to figure 6 , and are not shown here. We investigate the case where $\alpha^{G}=0.1$.

This model is identical to the main model when $\phi_{0}^{S}=1$ and $\phi_{1}^{S}=\phi_{2}^{S}=\phi_{3}^{S}=0$. The most noticeable difference between the two first columns of figures 6 and 3 is investment responses. When there is no time-to-build for private capital, investment falls much more in the short run and rises before returning to steady state. With the assumption of one year to build for private capital, the decline in the private investment in the short run is much smaller but now investment never rises. In the earlier explanation, private investment rises in later years mainly because of rising marginal product of capital due to more productive public capital. While this incentive still exists with time-to-build for private capital, private investment now represents the moving average of investment initiated each period. The decision to reduce investment in the initial five to ten years is spread over a longer period of time so that the later incentive to invest more is offset by earlier declines.

Overall, our earlier finding that the implementation delays in government investment can prolong and deepen the negative private investment responses still holds under time-to-build for private capital. In addition, we still find labor and output have tiny initial responses when there are implementation delays in government investment, while they jump up on imapct when there are no implementation delays. At longer horizons, as in figure 3, government investment contracts output when capital taxes are raised to stabilize debt. ${ }^{25}$

4.3. A Two-Sector Model with Government Production. Unlike the models to this point, actual governments employ workers and purchase intermediate goods and services to produce government consumption and investment goods that perform various public services (national defense, public order and safety, transportation, education, etc.). Like firms, government also rents labor from private agents. The macroeconomic literature generally does not model government as a separate production sector. To examine more closely the

\footnotetext{
${ }^{25}$ Responses under adjustments by labor income taxes and government consumption are qualitatively the same as (but slightly less expansionary than) those under transfers adjustment.
} 

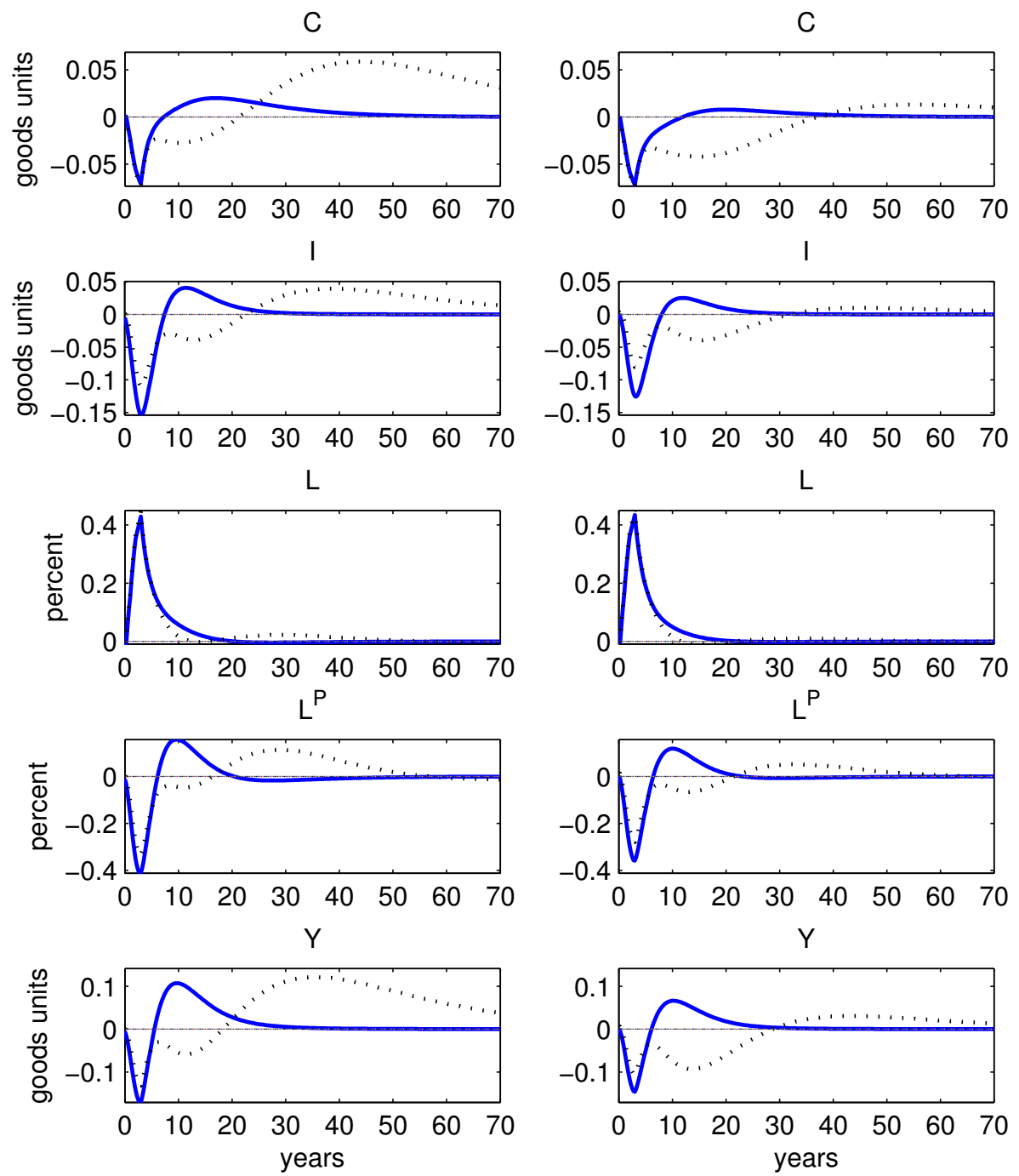

FIGURE 7. Impulse responses to higher government investment in a two-sector model with government production. Solid lines: transfers adjust; dotteddashed lines: capital income taxes adjust. First column: $\alpha^{G}=0.1$ and $N=12$; second column: $\alpha^{G}=0.05$ and $N=12$.

employment impacts of an increase in government investment, we change the model specification in section 2 , so that government combines intermediate goods and labor to produce government output similar to Cavallo (2005). ${ }^{26}$ We broadly define labor devoted to government production $\left(L_{t}^{G}\right)$ to include jobs paid for with government resources. For example, if

\footnotetext{
${ }^{26}$ Cavallo (2005) does not distinguish between government consumption and investment.
} 
a government agency contracts an infrastructure project to a private construction firm, the jobs generated by this project are labeled as $L_{t}^{G}$ in the model. ${ }^{27}$

The output of the economy $\left(Y_{t}\right)$ is the sum of private output $\left(Y_{t}^{P}\right)$ and government output $\left(Y_{t}^{G}\right)$

$$
Y_{t}=Y_{t}^{P}+Y_{t}^{G}
$$

Private output is produced by a Cobb-Douglas technology

$$
Y_{t}^{P}=A^{P} K_{t-1}^{\alpha_{K}}\left(L_{t}^{P}\right)^{\alpha_{L}}\left(K_{t-1}^{G}\right)^{\alpha_{G}},
$$

where $A^{P}$ is the total factor productivity for the private technology and $L_{t}^{P}$ is labor employed by the private sector. Since private production is assumed to be perfectly competitive, the zero profit condition implies

$$
Y_{t}^{P}=r_{t} u_{t} K_{t-1}+w_{t} L_{t}^{P}
$$

Government hires workers and purchases intermediate goods and services $\left(\widetilde{G}_{t}\right)$ to produce output with a Cobb-Douglas technology

$$
Y_{t}^{G}=A^{G}\left(L_{t}^{G}\right)^{\alpha_{L}}\left(\widetilde{G}_{t}\right)^{1-\alpha_{L}}
$$

where $A^{G}$ is the total factor productivity for the government production. The government sector produces government consumption $\left(G_{t}^{C}\right)$ and government investment $\left(G_{t}^{I}\right)$, which accumulates into public capital in the future for private production. The net contribution of government production to the final output in the economy is then

$$
Y_{t}^{G}=G_{t}^{C}+G_{t}^{I}-\widetilde{G}_{t}
$$

In the model without government production, the cost of government spending is the expenditure on government consumption and investment. With government production, the cost is the expenditure on intermediate goods and the wage bill. The government's budget constraint becomes

$$
\tau_{t}^{L} w_{t} L_{t}+\tau_{t}^{K} r_{t} u_{t} K_{t-1}-T_{t}+B_{t}-R_{t-1} B_{t-1}=\widetilde{G}_{t}+w_{t} L_{t}^{G}
$$

In the National Income and Product Accounts (Table 3.10.5), the main cost of producing government consumption is compensation to government employees and purchases of intermediate goods and services. ${ }^{28}$ In our model, we assume that government pays the prevailing wage in the private sector, $w_{t}$, which equals the marginal productivity of labor for private production,

$$
w_{t}=\alpha_{L} \frac{Y_{t}^{P}}{L_{t}^{P}}
$$

so government's wage cost is $w_{t} L_{t}^{G}$.

The rental rate for private capital, $r_{t}$, becomes

$$
r_{t}=\alpha_{K} \frac{Y_{t}^{P}}{K_{t-1}} .
$$

\footnotetext{
${ }^{27}$ In the accounting by the Bureau of Labor Statistics, government employment refers to those directly employed by government agencies.

${ }^{28}$ The cost also includes depreciation of government fixed capital, which is a proxy for capital cost. This is a small part (less than one tenth) of the government consumption expenditures. Since we do not assume government uses public capital to produce its output, we ignore this cost here.
} 
Labor can move costlessly between the two production sectors and aggregate labor is the sum of labor inputs in the two sectors,

$$
L_{t}=L_{t}^{P}+L_{t}^{G}
$$

The aggregate resource constraint is

$$
C_{t}+I_{t}+\psi\left(u_{t}\right) K_{t-1}+G_{t}^{C}+G_{t}^{I}=Y_{t}{ }^{29}
$$

The model introduces a new fiscal variable $\widetilde{G}_{t}$. We assume that

$$
\widetilde{G}_{t}=z\left(G_{t}^{C}+G_{t}^{I}\right), \quad 0<z<1 .
$$

This means government increases the purchase of intermediate goods and services proportionally to the gross government output. The rest of the setup for preferences and government fiscal policy are the same as in section 2 .

To calibrate this economy, we assume that in steady state, $\frac{L^{G}}{L}=0.2$, which is identical to the government consumption and investment share of total output $\left(\frac{G^{C}+G^{I}}{Y}\right)$. The value of $z$ in (29) is set to the ratio of the sum of intermediate goods and services purchased and government investment to the sum of government consumption and investment for 2007 (line 6 of NIPA Table 3.10.5, and lines 1 and 3 of NIPA Table 3.9.5); this gives $z=0.55$. The transfer-output ratio is reset to 0.08 to yield $s^{B}=1.59$. Some fiscal adjustment parameters are also modified to yield a valid solution: $q_{K}=0.08$ and $q_{C}=-0.05$. This calibration requires the total factor productivity for the government production to be $A^{G}=0.98$, close to the value of $A^{P}=1$ for the private production.

Figure 7 plots the impulse responses to an cumulative one-unit good increase in government investment under $\alpha^{G}=0.1$ (first column) and $\alpha^{G}=0.05$ (second column). Both columns assume three years to build public capital. Again, we only plot responses under transfers and capital income tax adjustments because responses under adjustments by labor income taxes and government consumption are relatively close to those under transfers adjustments.

A model with government production explicitly captures the competition for goods and labor due to an increase in government spending. In a model without government production, the increase in aggregate labor is due to the crowding-out effect or negative wealth effect. The private sector feels poorer and reduces consumption. This drives up the value of work. Labor supply increases, raising aggregate employment and reducing the wage rate. ${ }^{30}$ The prediction that higher government spending lowers wages, however, is at variance with empirical evidence that finds the opposite [Rotemberg and Woodford (1992), Fatas and Mihov (2001), and Gali, Lopez-Salido, and Valles (2007)]. ${ }^{31}$ The addition of government production, on the other hand, predicts a rising wage rate following an increase in government spending.

\footnotetext{
${ }^{29}$ Appendix A contains the derivation of this constraint, and shows the accounting consistency for the income and product sides in this model.

${ }^{30}$ Seitz (1994) investigates the impact of provision of public capital on demand for private inputs using German data. He finds a negative relationship between public capital and demand for private labor.

${ }^{31}$ Studies using the narrative approach based on war dummies, however, find that an increase in war spending leads to a lower wage rate [see Edelberg, Eichenbaum, and Fisher (1999) and Ramey and Shapiro (1998)].
} 
Government draws additional labor for its production when it increases government investment. The higher government demand for labor raises aggregate employment and the wage rate, in contrast to models without government production.

In response to a rising wage rate, private labor falls (the fourth row in figure 7), lowering the marginal product of private capital; output falls in the short run across all financing methods whether there are implementation delays or not. ${ }^{32}$ While we do not present responses under no implementation delays, the short-run dynamics are dominated by the negative impact on private production from a rising wage rate. The initial fall in output is the smallest when government investment is subject to longest time to build. Because the spending rate is small each period when time-to-build is long, the labor drawn by government production is also small and hence only a modest increase in the wage rate.

Compared to the earlier results without government production (figure $3, \alpha^{G}=0.1$ ), private investment falls much more in the case of government production. In addition to the crowding-out effect and wealth effect, when government draws labor to produce, the falling marginal product of private capital due to smaller private labor inputs amplifies the original reduction in private investment. With a larger decline in output, consumption also falls more relative to the case without government production.

In later years, one noticeable difference from the model without government production is the case under capital tax adjustments. Without government production, output falls substantially in later years, but stays positive with government production under $\alpha^{G}=0.1$ for a long period before returning to the steady state. Under the fiscal policy rules in (12)-(15), when the debt-output ratio falls below the steady state, the capital tax rate falls automatically to increase debt to its steady state level. In this model, as output falls significantly initially, the debt-output ratio drops quickly. Under our calibration, the capital tax rate over reacts and drives debt-output ratio below the steady state. Consequently, the capital tax rate falls, which drives up output in the later period. The influence of the productiveness of public capital can still be seen by comparing the output responses in the first and second columns in figure 7: output rises much less in later years when public capital is less productive.

In this model with government production, we explicitly model the channel by which government spending directly "creates" jobs. The results show that more jobs generated by government spending does not necessarily translate into higher output. In contrast, the increased labor demand drives up the wage rate, which reinforces the contractionary effects in the short run.

Some economists would argue that in a recession there are idle labor resources, so government production does not raise wages and crowd out private employment. Our model, and most macro models, cannot address this point. Since government investment is likely to be subject to substantial implementation delays, it is quite possible that some of the government investment will occur when the economy is already on its way to recovery. In that

\footnotetext{
${ }^{32}$ Finn (1998) finds that to a positive government employment shock, output, consumption, private investment, and private labor fall, and average labor productivity rises. Our results from rising government employment is consistent with her findings. In her model, government is not modeled as a separate production sector and government spending is not linked with government labor as in our setup.
} 
circumstance, competition from production factors from increasing government spending can lead to the economic effects as captured in the model with government production.

\section{Government Investment Present-Value Multipliers}

Government spending multipliers are often used to summarize the stimulative effects of fiscal policy. We compute the present-value cumulative multipliers over 1000 years for output, consumption, and private investment responses to a shock that raises the present value of government investment by one dollar. The length of 1000 years is long enough that our calculations account for all the responses to the shock. The discount factor is constructed based on the path of the interest rate responses. Compared with other measures of multipliers, such as peak responses to an initial change in a fiscal policy variable (as reported in Blanchard and Perotti (2002)) or cumulative multipliers based on simple sums, our calculation gives a higher multiplier if the expansionary effect is more front-loaded relative to the alternative pattern. For deficit-financed spending increases, where the cost of a stimulus also includes debt service, this distinction is particularly important.

Actual government financing uses a complicated mix of fiscal adjustments [see Chung and Leeper (2007) or Leeper, Plante, and Traum (2009)]. To compute multipliers, we consider two classes of fiscal adjustments: all fiscal instruments, distorting and non-distorting, or only lump-sum transfers adjust. When all the instruments adjust, the weight on each instrument is calibrated to those estimated from data, as described in section 2.3. Because adjustment in lump-sum taxes is the most common assumption imposed in macroeconomic studies, the multipliers based only on lump-sum financing reveal the potential bias introduced by not accounting for distorting financing.

Tables 3, 4, and 5 present the multipliers for both the distorting and the non-distorting financing schemes and across four model specifications. The models are: M1 (main model in section 2); M2 (government consumption and private consumption are complements - section 4.1; M3 (time-to-build for private capital — section 4.2); M4 (government production — section $4.3)$.

Productivity of public capital, $\alpha^{G}$, is the dominant factor determining the size of government investment multipliers. Since implementation delays mainly affect short-run dynamics, they have relatively small effects on present-value multipliers. When $\alpha^{G}=0.1$, output, consumption, and investment multipliers are larger than those under $\alpha^{G}=0.05$ across the four specifications of the models (the main model in section 2 and three alternative specifications in section 4).

Multipliers are uniformly larger - often much larger - when government investment is financed by lump-sum transfers. When public capital is relatively productive $\left(\alpha_{G}=0.1\right)$, output multipliers over two are commonplace under lump-sum financing. When government capital is relatively unproductive $\left(\alpha_{G}=0.05\right)$, the output multipliers are still larger than 1 for most models. Even with lump-sum transfers financing, the range of output multipliers is quite large: they can even be negative when $\alpha_{G}=0.05$ and government hires labor and intermediate goods to produce its spending goods (M4) because private production falls sharply due to a rising wage rate during initial years. 


\begin{tabular}{c|cc|cc|cc|cc} 
& \multicolumn{2}{|c|}{ M1 } & \multicolumn{2}{c|}{$\mathrm{M} 2$} & \multicolumn{2}{c|}{$\mathrm{M} 3$} & \multicolumn{2}{c}{$\mathrm{M} 4$} \\
\hline \hline$\alpha^{G}=0.1$ & & & & & & & & \\
1 Q delay & 2.05 & $(3.10)$ & 1.13 & $(2.58)$ & 1.77 & $(2.79)$ & 0.95 & $(1.51)$ \\
1Y delay & 2.18 & $(2.98)$ & 1.30 & $(2.48)$ & 1.99 & $(2.76)$ & 1.65 & $(1.29)$ \\
3Y delay & 1.74 & $(2.76)$ & 0.93 & $(2.29)$ & 1.85 & $(2.67)$ & 1.17 & $(1.06)$ \\
\hline$\alpha^{G}=0.05$ & & & & & & & & \\
1Q delay & -0.25 & $(1.89)$ & -0.46 & $(1.69)$ & 0.12 & $(1.81)$ & -1.61 & $(0.24)$ \\
1Y delay & -0.02 & $(1.82)$ & -0.22 & $(1.63)$ & 0.37 & $(1.79)$ & -0.81 & $(0.07)$ \\
3Y delay & -0.22 & $(1.72)$ & -0.38 & $(1.55)$ & 0.30 & $(1.75)$ & -1.01 & $(-0.02)$
\end{tabular}

TABle 3. Present-value output multipliers. M1 is the main model (section 2). M2 is the model where government consumption is a complement to private consumption (section 4.1). M3 is the model with time-to-build for private capital (section 4.2). M4 is the model with government production (section 4.3). Multipliers computed assuming all government fiscal instruments adjust to stabilize debt. Numbers in parentheses are multipliers when only lump-sum taxes adjust to stabilize debt.

\begin{tabular}{c|cc|cc|cc|cc} 
& \multicolumn{2}{|c|}{$\mathrm{M} 1$} & \multicolumn{2}{c|}{$\mathrm{M} 2$} & \multicolumn{2}{c|}{$\mathrm{M} 3$} & \multicolumn{2}{c}{$\mathrm{M} 4$} \\
\hline \hline$\alpha^{G}=0.1$ & & & & & & & & \\
1 Q delay & 0.99 & $(1.42)$ & 0.44 & $(1.01)$ & 0.87 & $(1.28)$ & 0.08 & $(0.34)$ \\
1Y delay & 1.03 & $(1.36)$ & 0.50 & $(0.96)$ & 0.95 & $(1.26)$ & 0.34 & $(0.19)$ \\
3Y delay & 0.81 & $(1.23)$ & 0.33 & $(0.86)$ & 0.86 & $(1.19)$ & 0.06 & $(0.02)$ \\
\hline$\alpha^{G}=0.05$ & & & & & & & & \\
1Q delay & -0.36 & $(0.52)$ & -0.48 & $(0.36)$ & -0.20 & $(0.48)$ & -1.51 & $(-0.67)$ \\
1Y delay & -0.27 & $(0.48)$ & -0.39 & $(0.34)$ & -0.10 & $(0.47)$ & -1.19 & $(-0.79)$ \\
3Y delay & -0.38 & $(0.42)$ & -0.47 & $(0.29)$ & -0.15 & $(0.43)$ & -1.30 & $(-0.86)$
\end{tabular}

TABLE 4. Present-value consumption multipliers. See the caption under table 3 for details.

\begin{tabular}{c|cc|cc|cc|cc} 
& \multicolumn{2}{|c|}{$\mathrm{M} 1$} & \multicolumn{2}{c|}{$\mathrm{M} 2$} & \multicolumn{2}{c|}{$\mathrm{M} 3$} & \multicolumn{2}{c}{$\mathrm{M} 4$} \\
\hline \hline$\alpha^{G}=0.1$ & & & & & & & & \\
1 Q delay & 0.25 & $(0.66)$ & 0.07 & $(0.60)$ & -0.09 & $(-0.08)$ & -0.88 & $(-0.64)$ \\
1Y delay & 0.12 & $(0.44)$ & -0.07 & $(0.36)$ & -0.11 & $(-0.10)$ & -1.05 & $(-1.05)$ \\
3Y delay & -0.29 & $(0.09)$ & -0.50 & $(-0.01)$ & -0.12 & $(-0.11)$ & -1.44 & $(-1.39)$ \\
\hline$\alpha^{G}=0.05$ & & & & & & & & \\
1Q delay & -0.59 & $(0.15)$ & -0.64 & $(0.11)$ & -0.057 & $(-0.05)$ & -1.51 & $(-0.99)$ \\
1Y delay & -0.61 & $(0.02)$ & -0.67 & $(-0.04)$ & -0.058 & $(-0.05)$ & -1.56 & $(-1.30)$ \\
3Y delay & -0.78 & $(-0.14)$ & -0.85 & $(-0.20)$ & -0.062 & $(-0.06)$ & -1.69 & $(-1.42)$
\end{tabular}

TABle 5. Present-value investment multipliers. See the caption under table 3 for details. 
When distorting fiscal instruments finance government investment, the output multipliers range from 2.18 to -1.61 . When $\alpha^{G}=0.1$, most cases have the output multipliers are bigger than 1 . When $\alpha^{G}=0.05$, the only model that delivers a positive multiplier is when there is time-to-build for private capital, mainly because total private investment falls less.

The consumption multipliers range from 1.03 to -1.51 with distorting financing and from 1.42 to -0.86 with lump-sum transfers financing. While all consumption multipliers with distorting financing are negative when $\alpha^{G}=0.05$, the majority are only slightly negative, with the exception of the model with government production.

Finally, the investment multipliers range from 0.25 to -1.69 with distorting financing and from 0.66 to -1.42 with lump-sum transfers financing. For most models we examine, the investment multipliers are negative with only a few exceptions. Since investment falls universally during the beginning years before turning positive for the models and calibrations we examine, the cumulative, present-value multipliers are likely to be negative even though investment turns positive in later years. Despite the small effect of implementation delays on cumulative multipliers, there is some influence on private investment responses: the longer the delay in government investment, the smaller the investment multipliers within a model for a given $\alpha^{G}$.

The results presented here suggest a wide range of multipliers for government investment. These multipliers are computed under the assumptions that either all fiscal instruments or only lump-sum transfers are adjust to stabilize debt. If government relies more on raising capital taxes, multipliers can become much more negative for all three variables. On the other hand, if government relies more on cutting lump-sum transfers or raising labor income taxes, multipliers can be larger. Finally, given the large difference in the output multipliers between $\alpha^{G}=0.1$ and $\alpha^{G}=0.05$, the importance of productivity of public capital for fiscal stimulus is apparent.

\section{Concluding Remarks}

This paper studies the macroeconomic effects of government investment in the short run and long run. We show that a substantial time-to-build lag in a standard neoclassical model can make expansions in government investment contractionary in the short run, at worst, and have a muted impact, at best. This outcome is robust across different assumptions on fiscal adjustments, productivities of public capital, the role of government consumption, and timeto-build for private capital. It is also robust to assuming that the government is a production sector, where government investment directly generates jobs. Over longer horizons, we show that the choice of fiscal adjustment instruments is important for minimizing the negative effects from stabilizing government debt. The productivity of government investment is also critical. The more productive is public capital, the less likely it is that government investment is contractionary in the long run.

The neoclassical framework we employ is completely standard in macroeconomic research. Nonetheless, it has its limitations, particularly in addressing the circumstances surrounding the recession of 2007-2009. For example, one characteristic of the macroeconomic policy response to the recession was that both fiscal policy and monetary policy reacted aggressively. In fact, the Federal Reserve drove the federal funds rate to its zero bound in its efforts to 
stimulate demand. Recent work has shown that government spending multipliers can be substantially larger when coupled with such a monetary policy response [see, for example, Christiano, Eichenbaum, and Rebelo (2009) and Davig and Leeper (2009) who study only unproductive government spending in models with nominal rigidities].

Despite its simplicity, the neoclassical model does highlight two important mechanisms at work in the current environment: large government infrastructure projects take time to build and, therefore, can have rather different impacts in the short run than in the long run; how government investment ultimately gets financed matters a great deal for the longrun consequences of any fiscal package with a substantial infrastructure component. Both mechanisms are integral to making accurate predictions of the effects of fiscal expansions from government investment. 


\section{Appendix A. Deriving Aggregate Resource Constraint in the Model with} Government Production

Rewrite the government flow budget constraint of (24) as

$$
T_{t}=\tau_{t}^{L} w_{t} L_{t}+\tau_{t}^{K} r_{t} u_{t} K_{t-1}+B_{t}-R_{t-1} B_{t-1}-\widetilde{G}_{t}-w_{t} L_{t}^{G}
$$

Combining (30) with the agent's budget constraint (3), and then applying the aggregate labor constraint (27) to get

$$
C_{t}+I_{t}+\psi\left(u_{t}\right) K_{t-1}+\widetilde{G}_{t}=r_{t} u_{t} K_{t-1}+w_{t} L_{t}^{P} .
$$

Using the equilibrium condition (22) for private prediction in (31), we obtain an expression for private output,

$$
Y_{t}^{P}=C_{t}+I_{t}+\psi\left(u_{t}\right) K_{t-1}+\widetilde{G}_{t} .
$$

Next, combine private output (32) with the expression for government output (23), we have

$$
Y_{t}^{P}+Y_{t}^{G}=C_{t}+I_{t}+\psi\left(u_{t}\right) K_{t-1}+G_{t}^{C}+G_{t}^{I}=Y_{t}
$$

which is equivalent to equation (8). Since the product side and income side of an economy must coincide, the model implies the resource value of government output equals the cost to produce them. In other words,

$$
G_{t}^{C}+G_{t}^{I}=\widetilde{G}_{t}+w_{t} L_{t}^{G}
$$

To check aggregate income of the economy, combine (22), (23), (34), and (27) to obtain

$$
\begin{aligned}
& Y_{t}^{P}+Y_{t}^{G} \\
= & \underbrace{r_{t} u_{t} K_{t-1}+w_{t} L_{t}^{P}}_{Y_{t}^{P}}+\underbrace{G_{t}^{C}+G_{t}^{I}-\widetilde{G}_{t}}_{Y_{t}^{G}} \\
= & r_{t} u_{t} K_{t-1}+w_{t} L_{t}^{P}+w_{t} L_{t}^{G} \\
= & r_{t} u_{t} K_{t-1}+w_{t} L_{t} .
\end{aligned}
$$




\section{REFERENCES}

Abel, A. B. (1990): "Asset Prices under Habit Formation and Catching Up with the Joneses," American Economic Review Papers and Proceedings, 80(2), 38-42.

Ahmed, S. (1986): "Temporary and Permanent Government Spending in an Open Economy," Journal of Monetary Economics, 17(2), 197-224.

Amato, J. D., And T. LAubach (2004): "Implications of Habit Formation for Optimal Monetary Policy," Journal of Monetary Economics, 51, 305-325.

Ambler, S., And A. Paquet (1996): "Fiscal Spending Shocks, Endogenous Government Spending, and Real Business Cycles," Journal of Economic Dynamics and Control, 20, $237-256$.

Aschauer, D. A. (1985): "Fiscal Policy and Aggregate Demand," American Economic review, $75(1$ (March)).

Aschauer, D. A. (1989a): "Does Public Capital Crowd Out Private Capital?," Journal of Monetary Economics, 24(2(September)), 171-188.

- (1989b): "Is Public Expenditure Productive?," Journal of Monetary Economics, 23(2(March)), 177-200.

(1990): "Is Government Spending Stimulative?," Contemporary Economic Policy, $8(4), 30-46$.

Barro, R. J. (1989): "The Neoclassical Approach to Fiscal Policy," in Modern Business Cycle Theory, ed. by R. J. Barro, pp. 178-235. Harvard University Press, Cambridge, MA.

- (1990): "Government Spending in a Simple Model of Endogenous Growth," Journal of Political Economy, 98(5, Part 2), S103-S125.

Baxter, M., And R. G. King (1993): "Fiscal Policy in General Equilibrium," American Economic Review, 86, 1154-1174.

Blanchard, O. J., and R. Perotti (2002): "An Empirical Characterization of the Dynamic Effects of Changes in Government Spending and Taxes on Output," Quarterly Journal of Economics, 117(4), 1329-1368.

Bouakez, H., And N. Rebei (2007): "Why Does Private Consumption Rise After a Government Spending Shock?," Canadian Journal of Economics, 40(3), 954-979.

Burnside, C., And M. Eichenbaum (1996): "Factor-Hoarding and the Propagation of Business-Cycle Shocks," American Economic Review, 86(5), 1154-1174.

Burnside, C., M. Eichenbaum, And J. D. M. Fisher (2004): "Assessing the Effects of Fiscal Shocks," Journal of Economic Theory, 115(1), 89-117.

Cavallo, M. (2005): "Government Employment Expenditure and the Effects of Fiscal Policy Shocks," Federal Reserve Bank of San Francisco Working Paper 2005-16.

Christiano, L. J., M. Eichenbaum, and C. L. Evans (2005): "Nominal Rigidities and the Dynamic Effects of a Shock to Monetary Policy," Journal of Political Economy, $113(1), 1-45$.

Christiano, L. J., M. Eichenbaum, and S. Rebelo (2009): "When Is the Government Spending Multiplier Large?," Manuscript, Northwestern University.

Chung, H., And E. M. Leeper (2007): "What Has Financed Government Debt?," NBER Working Paper No. 13425.

Congressional Budget Office (2007): The Long-Term Budget Outlook, vol. December. Washington, D.C.

- (2008): Options for Responding to Short-Term Economic Weakness, vol. January. Washington, D.C. 
(2009a): Estimated Macroeconomic Impacts of the American Recovery and Reinvestment Act of 2009, vol. March. Washington, D.C.

(2009b): A Preliminary Analysis of the President's Budget and an Update of CBO's Budget and Economic Outlook. Washington, D.C., http://www.cbo.gov/ftpdocs/100xx/doc10014/03-20-PresidentBudget.pdf.

Congressional Quarterly Press (2006): Congress and the Nation Series. Congressional Quarterly Inc., Washington, D.C., 1945-2004 edn.

Davig, T., And E. M. Leeper (2009): "Monetary-Fiscal Policy Interactions and Fiscal Stimulus," Manuscript, Indiana University.

Dennis, R. (2008): "Consumption-Habits in a New Keynesian Business Cycle Model," Federal Reserve Bank of San Francisco Working Paper 2008-35.

Economic Report of the President (2009): United States Government Printing Office. Washington, D.C.

Edelberg, W., M. Eichenbaum, and J. D. M. Fisher (1999): "Understanding the Effects of a Shock to Government Purchases," Review of Economic Dynamics, 2(1), 166206.

Elmendorf, D. W. (2009): Implementation Lags of Fiscal Policy. Washington, D.C.

Evans, P., And G. Karras (1994): "Are Government Activities Productive? Evidence from a Panel of U.S. States," Review of Economic and Statistics, 76(1), 1-11.

Fatas, A., And I. Mihov (2001): "The Effects of Fiscal Policy on Consumption and Employment: Theory and Evidence," Mimeo, INSEAD.

Federal Highway Administration (2002): Introduction to JOBMOD A Federal-Aid Construction Spending Income and Employment Estimation Model. U.S. Department of Transportation, Washington, D.C.

Finn, M. (1993): "Is All Government Capital Productive?," Federal Reserve Bank of Richmond Economic Quarterly, 79(4), 53-80.

Finn, M. G. (1998): "Cyclical Effects of Government's Employment and Goods Purchases," International Economic Review, 39(3), 635-657.

Friedman, B. M. (2005): "Deficits and Debt in the Short and Long Run," in The Macroecoomics of Fiscal Policy, ed. by R. W. Kopcke, G. M. B. Tootell, and R. K. Triest. MIT, Cambridge.

Gali, J., J. D. Lopez-Salido, and J. Valles (2007): "Understanding the Effects of Government Spending on Consumption," Journal of the European Economic Association, 5(1), 227-270.

Glomm, G., and B. Ravikumar (1997): "Productive Government Expenditures and Long-Run Growth," Journal of Economic Dynamics and Control, 21, 183-204.

- (1999): "Competitive Equilibrium and Public Investment Plans," Journal of Economic Dynamics and Control, 23, 1207-1224.

Gramlich, E. M. (1994): "Infrastructre Investment: a Review Essay," Journal of Economic Literature, 32(3), 1176-1196.

Holtz-Eakin, D. (1994): "Public-Sector Capital and the Productivity Puzzle," Review of Economic and Statistics, 76(1), 12-21.

House, C. L., And M. D. Shapiro (2006): "Phased-in Tax Cuts and Economic Activity," American Economic Review, 96(5), 1835-1849.

Joint Committee on TAXation (2001): Estimated Budget Effects of the Conference Agreement of H.R. 1836. Washington, D.C., http://www.jct/gov/x-51-01.pdf. 
Jones, J. B. (2002): "Has Fiscal Policy Helped Stabilize the Postwar U.S. Economy?," Journal of Monetary Economics, 49(May), 709-746.

Kamps, C. (2004): The Dynamic Macroeconomic Effects of Public Capital. Springer, Berlin, Bermany.

Kano, T., And J. M. NAson (2008): "Business Cycle Implications of Internal Consumption Habit for New Keynesian Models," Manuscript.

Karras, G. (1994): "Government Spending and Private Consumption: Some International Evidence," Journal of Money, Credit and Banking, 26(1), 9-22.

Kormendi, R. C. (1983): "Government Debt, Government Spending, and Private Sector Behavior," American Economic Review, 73(5), 994-1010.

Kydland, F., and E. C. Prescott (1982): "Time to Build and Aggregate Fluctuations," Econometrica, 50, 1345-1370.

LAU, S.-H. P. (1995): "Welfare-Maximizing vs. Growth-Maximizing Shares of Government Investment and Consumption," Economic Letters, 47, 351-159.

Leeper, E. M., M. Plante, and N. Traum (2009): "Fiscal Financing in the United States," Manuscript, Indiana University.

Leeper, E. M., T. B. Walker, And S.-C. S. YAng (2008): "Fiscal Foresight: Analytics and Econometrics," NBER Working Paper No. 14028.

- (2009): "Fiscal Foresight and Information Flows," NBER Working Paper No. 14630.

Leeper, E. M., And S.-C. S. YAng (2008): "Dynamic Scoring: Alternative Financing Schemes," Journal of Public Economics, 92, 159-182.

McCallum, B., and E. Nelson (1999): "Nominal Income Targeting in an Open Economy Optimizing Model," Journal of Monetary Economics, 43, 553-578.

McGrattan, E. R. (1994): "The Macroeconomic Effects of Distortionary Taxation," Journal of Monetary Economics, 33(3), 573-601.

Monacelli, T., And R. Perotti (2008): "Fiscal Policy, Wealth Effects, and Markups," NBER Working Paper No. 14584.

Montgomery, M. R. (1995): "Time-to-Build Completion Patterns for Nonresidential Structures, 1961-1991," Economics Letters, 48, 155-163.

Munnell, A. H. (1992): "Policy Watch: Infrastructure Investment and Economic Growth," Journal of Econoic Perspectives, 6(4), 189-198.

Nadiri, M. I., And T. P. Mamuneas (1994): "The Effects of Public Infrastructure and R \& D Capital on the Cost Structure and Performance of U.S. Manufacturing Industries," Review of Economic and Statistics, 76(1), 22-37.

Ni, S. (1995): "An empirical analysis on the substitutability between private consumption and government purchases," Journal of Monetary Economics, 36(3), 593-605.

Pereira, A. M., and R. F. De Frutos (1999): Journal of Urban Economics46, 300-322. Ramey, V. A. (2008): "Identifying Government Spending Shocks: It's All in the Timing," Manuscript, University of California, San Diego.

Ramey, V. A., And M. D. Shapiro (1998): "Costly Capital Reallocation and the Effects of Government Spending," Carneige-Rochester Conference Series on Public Policy, 48, 145-194.

Ravn, M., S. Schmitt-Grohe, and M. Uribe (2006): "Deep Habits," Review of Economic Studies, 73, 195-218.

Romer, C., And J. Bernstein (2009): The Job Impact of the American Recovery and Reinvestment Plan. Obama Transition Team, Washington, D.C., January 9. 
Rotemberg, J. J., And M. Woodford (1992): "Oligopolistic Pricing and the Effects of Aggregate Demand on Economic Activity," Journal of Political Economy, 100(6), 11531207.

Schmitt-Grohe, S., And M. Uribe (2007): "Optimal Operational Monetary Policy in the Christiano-Eichenbaum-Evans Model of the U.S. Business Cycle," .

SEITz, H. (1994): "Public Capital and the Demand for Private Inputs," Journal of Public Economics, 54, 287-307.

Smets, F., And R. Wouters (2003): "An Estimated Dynamic Stochastic General Equilibrium Model of the Euro Area," Journal of the European Economic Association, 1(5), $1123-1175$.

- (2007): "Shocks and Frictions in U.S. Business Cycles: A Bayesian DSGE Approach," American Economic Review, 97(3), 586-606.

YAng, S.-C. S. (2005): "Quantifying Tax Effects Under Policy Foresight," Journal of Monetary Economics, 52(8), 1557-1568. 